
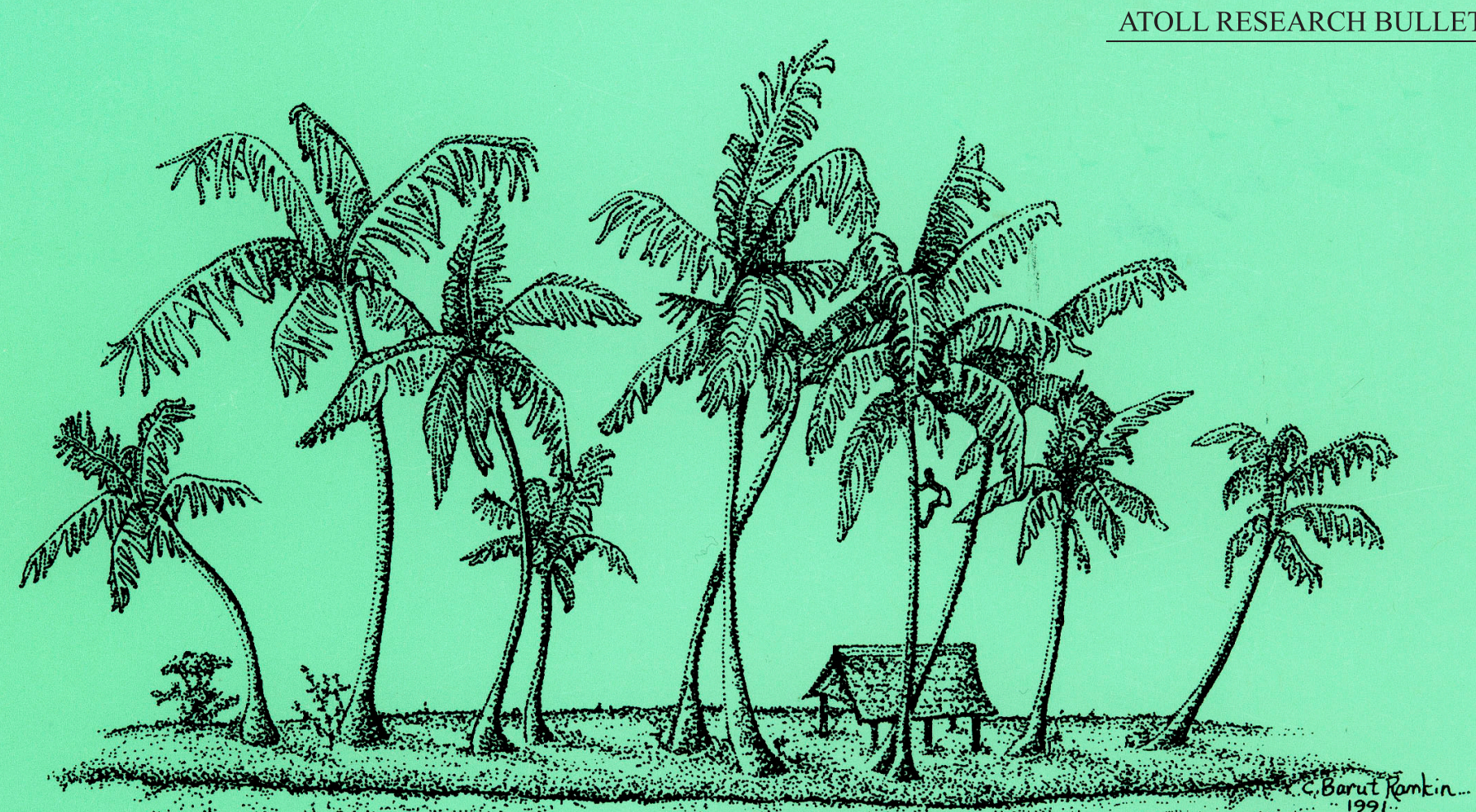

CARBONATE BEACH SAND OF ABAIANG ATOLL, KIRIBATI: GEOCHEMISTRY, BIOGENIC SOURCES, AND PROPERTIES

Joanna C. Ellison, Paul Han,
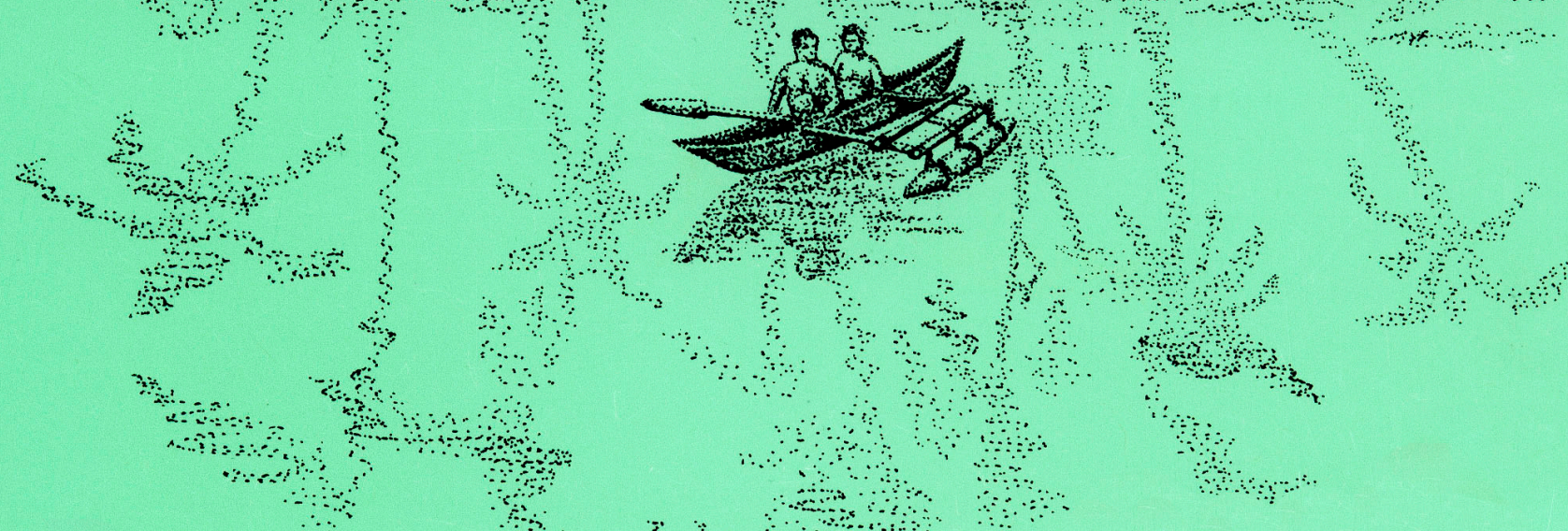

7 a

and Trevor W. Lewis

RESEARCH

Smithsonian Institution
Scholarly Press

BULLETIN 


\title{
CARBONATE BEACH SAND OF ABAIANG ATOLL, KIRIBATI: GEOCHEMISTRY, BIOGENIC SOURCES, AND PROPERTIES
}

\author{
Joanna C. Ellison, Paul Han, \\ and Trevor W. Lewis
}

Atoll Research Bulletin No. 621 20 March 2019

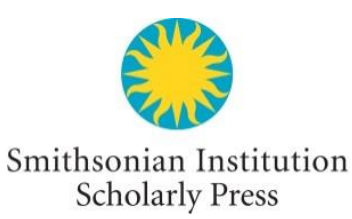

Washington, D.C. 
All statements made in papers published in the Atoll Research Bulletin are the sole responsibility of the authors and do not necessarily represent the views of the Smithsonian Institution or of the editors of the bulletin. Articles submitted for publication in the Atoll Research Bulletin should be original papers and must be made available by authors for open access publication. Manuscripts should be consistent with the "Author Formatting Guidelines for Publication in the Atoll Research Bulletin." All submissions to the bulletin are peer reviewed and, after revision, are evaluated prior to acceptance and publication through the publisher's open access portal, Open SI (https://opensi.si.edu).

Published by SMITHSONIAN INSTITUTION SCHOLARLY PRESS

P.O. Box 37012, MRC 957

Washington, D.C. 20013-7012

https://scholarlypress.si.edu/

The rights to all text and images in this publication are owned either by the contributing authors or by third parties. Fair use of materials is permitted for personal, educational, or noncommercial purposes. Users must cite author and source of content, must not alter or modify the content, and must comply with all other terms or restrictions that may be applicable. Users are responsible for securing permission from a rights holder for any other use.

ISSN: 0077-5630 (online) 


\section{CONTENTS}

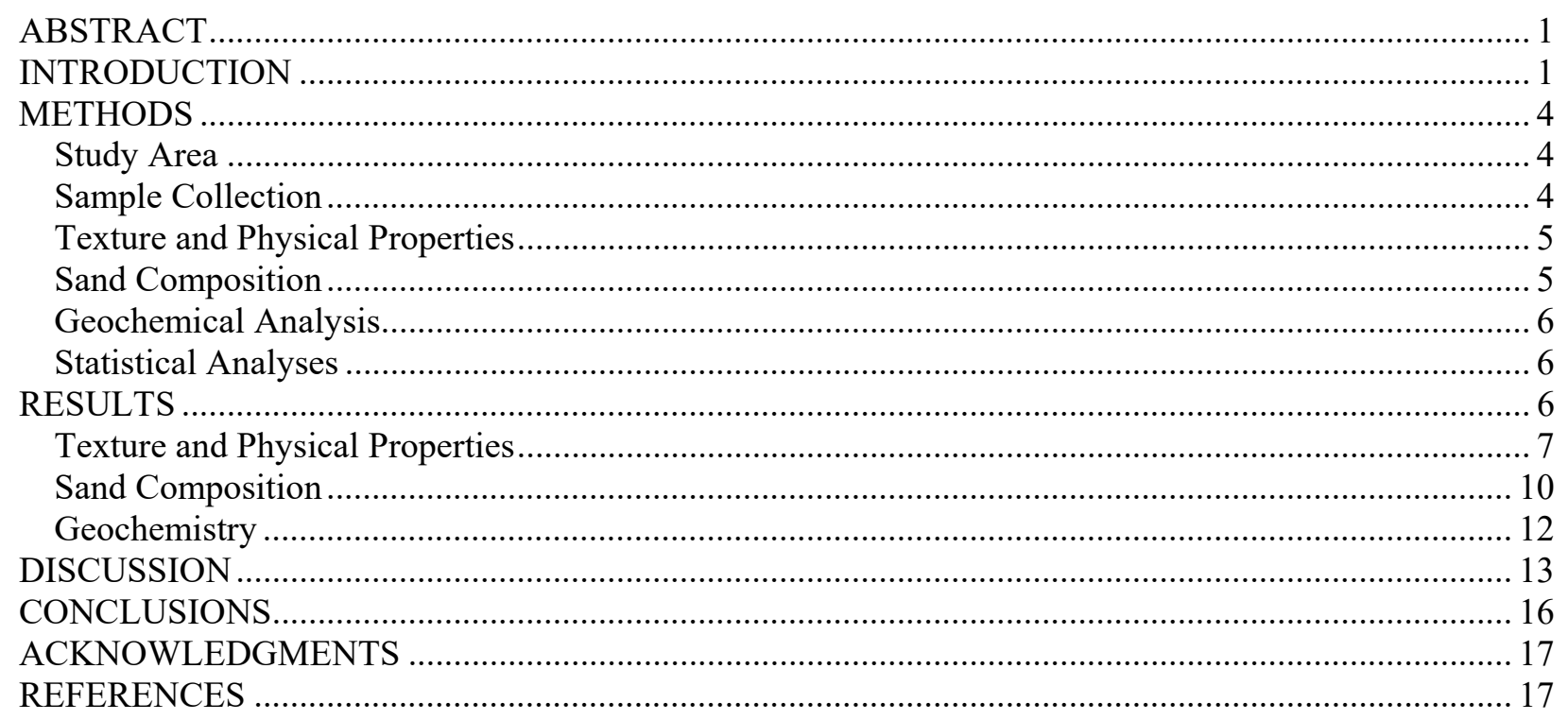




\title{
CARBONATE BEACH SAND OF ABAIANG ATOLL, KIRIBATI: GEOCHEMISTRY, BIOGENIC SOURCES, AND PROPERTIES
}

\author{
JOANNA. C. ELLISON ${ }^{1 *}$, PAUL HAN ${ }^{2}$, and TREVOR W. LEWIS ${ }^{2}$
}

\begin{abstract}
Sandy beaches are critical resources for low-lying Pacific atoll communities, providing protection during storms, and land area for many coastal villages. Information on the nature of atoll beach sediment, its geochemistry and composition, can help to establish priorities to effectively protect the sources of Pacific island beach sediment. To understand sand sources, this study evaluated its physical characteristics including grain-size, geochemistry and composition, from windward and leeward beach profiles around Abaiang Atoll, Kiribati. Beach sand was $>99 \%$ carbonate, averaging 37\% coral fragments, 30\% mollusc shells, $12 \%$ foraminifera, and $20 \%$ calcareous algae. Significant differences were found between reef and lagoonal sites in proportions of coral and mollusc fragments and foraminifera tests, with lagoon beaches having higher mollusc and coral proportions and lower foraminifera relative to reef beaches. This is attributed to high foraminiferal productivity offshore of reef beaches, and taphonomic durability of coral fragments in longshore drift into the lagoon. Mean sediment diameter increased from the upper to lower beaches at all sites, but fine sediment was lacking, attributed to its dissolution by rainfall and groundwater outflow. Geochemical analysis showed a mean of $84 \% \mathrm{Ca}-\mathrm{Mg}$ carbonates, of which $80 \%$ was calcium carbonate. There was no significant difference in the mean calcium percentage or calcium carbonate composition of the sediment between lagoon and reef beach sediment sources. Magnesium and magnesium carbonate content were significantly higher at reef sites relative to lagoon sites, attributed to higher proportions of foraminifera. Sediment-producing near shore habitats are critical to village protection through provision of beach sand, and this study shows the need to better conserve and manage coral reefs and habitats such as lagoon seagrass beds, to ensure continued atoll beach sand supply.
\end{abstract}

Keywords: Carbonate beach, Foraminifera, Molluscs, Texture, Geochemistry, Kiribati

\section{INTRODUCTION}

Sandy beaches around tropical atolls are essential to island communities (Fujuta et al., 2009) as a protective barrier to destructive waves, and a staging area for fishing and boat launching. Sand islands develop from subtidal gravels; as wave energy dissipates, intertidal sands accumulate supratidally to provide colonization space for vegetation (McKoy et al., 2010). Beaches have been favoured locales for human habitation in Pacific islands since initial human settlement, because conditions and substrates made boats easy to pull onto the shore (Dickinson, 2014). Although sandy beaches dominate atoll shorelines across the Pacific, studies of beach sand origins and composition are uncommon in literature for the region (Nel at al., 2014). Atolls that have been heavily modified by human activity such as Tarawa, Majuro (Fujita

${ }^{1}$ Discipline of Geography and Spatial Sciences, School of Technology, Environments and Design, University of Tasmania, Locked Bag 1370, Launceston, Tasmania 7520, Australia. "Corresponding author. e-mail: Joanna.Ellison@utas.edu.au

${ }^{2}$ School of Natural Sciences (Chemistry), University of Tasmania, Locked Bag 1370, Launceston, Tasmania 7250, Australia. 
et al., 2009; Yasukochi et al., 2014), Funafuti (Collen and Garton, 2004; Kench et al., 2014) and Palmyra (Collen et al., 2009) have better studied shorelines relative to unmodified atolls.

Beach sediments of atolls derive from nearshore biogenically-produced carbonate sand (Milliman, 1967; 1974; Stoddart and Steers, 1977; Gischler, 1994; Richmond, 2000; Yamano et al., 2002; Yamano et al., 2005; McKoy et al., 2010; Perry et al., 2011; Kench et al., 2014; McLean and Kench, 2015), primarily from coral, benthic foraminifera, calcareous algae, mollusc shells, spicules and echinoderm spines. Review of the composition of reef island beaches from 24 available studies (Perry et al., 2011) showed that most are foraminifera-dominant, a few are coral fragment-dominant, and only Caribbean atolls show dominance of the algae Halimeda. Foraminiferal tests can be produced in large numbers on reef crests in relatively pristine environments, but decline when nutrification occurs (Hallock, 2000). The major constituent of beach sand of Pacific atolls is foraminifera (Yamano et al., 2005), particularly Baculogypsina and Calcarina, thus are essential to this facies of atoll islands (Kayenne et al., 2002; Yasukochi et al., 2014; Kench et al., 2014).

Carbonate-dominant beaches can have a minerogenic proportion, which for beaches adjacent to continents or volcanic islands is quartz sand (Pilkey et al., 1967; Davies and Hudson, 1987), or derived from other igneous or metamorphic rocks (Friedman, 1968; Harney et al., 2000). However, a small noncarbonate proportion has also been reported from mid-ocean atoll beach sands (Forbes and Hosoi, 1995; Forbes and Solomon, 1997; Ellison et al., 2017), the nature of which has been little investigated.

Variability in carbonate beach composition may be due to benthic communities, differential erosion on the beach, or human impacts, and is important to understand sand supply to atoll shorelines (Ellison et al., 2017). Carbonate sediment is the most susceptible of all coastal sands to abrasion and dissolution (Pilkey et al., 1967). With sources from biogenic environments such as coral reefs, seagrass beds and molluscs, human impacts on these communities may reduce sand supply and lead to beach erosion (Ebrahim, 2000; Fujita et al., 2014), which is of wide concern in the Pacific islands region, particularly on inhabited shorelines (Forbes and Hosoi, 1995; Gillie, 1997; Mimura and Nunn, 1998; Duvat, 2013; Duvat et al., 2013; Donner, 2013; Nurse et al., 2014). With low lying reef islands being highly vulnerable to sea level rise (Duvat et al., 2013; Nurse et al., 2014), understanding the physical structure and composition of beach sediment is important in determining the sources and processes involved in sediment supply and erosion.

Atolls that have been heavily modified by human activity such as Tarawa, Majuro (Fujita et al., 2009; Yasukochi et al., 2014), Funafuti (Collen and Garton, 2004; Kench et al., 2014) and Palmyra (Collen et al., 2009) have better studied shorelines relative to unmodified atolls. Sediment characteristics of Tarawa atoll, Kiribati, have been studied at several locations following concerns about beach erosion, due to disruption of sediment supply by causeway construction (Richmond, 1990; Forbes and Hosai, 1995; Smith and Biribo, 1995; Ebrahim, 2000). On the ocean-facing shore of central South Tarawa, beach sand was described as almost 100\% carbonate (Forbes and Hosoi, 1995; Forbes and Solomon, 1997). Beach sand from Tarawa showed dominance by coral ( $44 \%$ on the ocean side and $40 \%$ on the lagoon shore), with similar levels of foraminifera (c. 37\%), as well as molluscs (c. 15\%) and Halimeda (c. 4\%) (Ebrahim, 2000).

Tarawa is the relatively well-studied capital atoll of the Republic of Kiribati, which includes 33 atolls dispersed across 2.5 million $\mathrm{km}^{2}$ of the equatorial Central Pacific Ocean (Figure 1). Twelve atolls are found in the western Gilbert Islands, including Tarawa and Abaiang (Goldberg, 2016), both of which have open lagoons, with navigable passages through the rim. To the north of Tarawa, Abaiang atoll $\left(1^{\circ} 51^{\prime} \mathrm{N} ; 172^{\circ}\right.$ 56 'E) has the $6^{\text {th }}$ largest land area of the western Gilbert group, with the $4^{\text {th }}$ largest lagoon area (Thaman et al., 1992). Larger atoll islands are the most stable, and may offer ongoing land resources and opportunities for future habitation relative to smaller islands (Kench et al., 2018). Abaiang has the fourth highest population of atolls in Kiribati, with 5,502 people recorded in the 2010 census. Economic activities include fishing and agriculture, largely for subsistence living, and its coastline is unmodified by causeways or seawalls. 


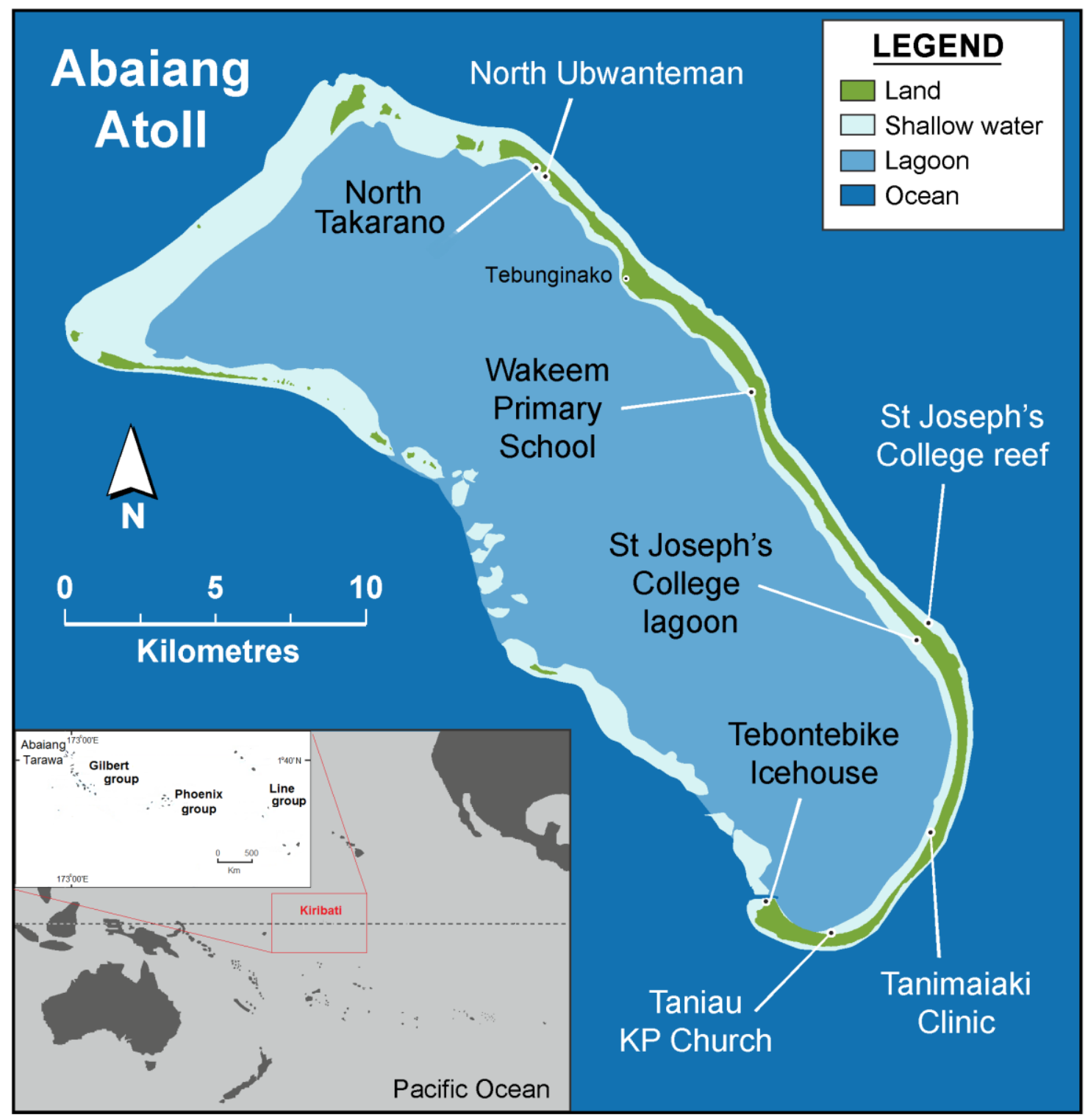

Figure 1. Map of Abaiang, Kiribati, showing study locations.

Local residents of Abaiang have submitted many reports of beach erosion threatening villages and infrastructure (Ministry of Internal and Social Affairs [MISA], 2008; Office of Teberetitenti, 2012). Extensive problems with coastal erosion on Abaiang have been documented, with 47 beach sites described (MISA, 2008), many adjacent to villages. At one location south of Tebunginako village, erosion resulted from ongoing adjustment of the shore to blocking of a natural channel from the western coast to the lagoon by causeway construction (Webb, 2006). Other shorelines, particularly on the lagoon shore where most villagers live, also have reported coastal erosion (Office of Teberetitenti, 2012), attributed to climate change, sea level rise and flooding of land during high sea surges (MISA, 2008).

The aim of this study was to investigate the characteristics of beach sediment from lagoon and reef beaches of Abaiang, including the compositional sources of the beach sand, and its physical and chemical characteristics. The objective was to enable better understanding of the sediment sources to the beaches, and identify differences across the island and between reef and lagoon beaches. Abaiang was selected as an unmodified large atoll adjacent to the well-studied and modified atoll of Tarawa, to enable comparison. Grain size properties were utilized to indicate the sources and distribution characteristics of the coastal and 
marine sediments (Edwards et al., 2005). Information relating to the nature of beach sediment, geochemistry and sand composition can aid management agencies to identify where the sand is derived, to establish priorities to protect the sources of coastal sediment of Pacific islands.

\section{METHODS}

\section{Study Area}

Abaiang lacks climate data, but $40 \mathrm{~km}$ south of Abaiang, the weather station at Betio on Tarawa shows mean monthly temperatures of $27-28^{\circ} \mathrm{C}$ and mean annual rainfall of $2,100 \mathrm{~mm}$ (Australian Bureau of Meteorology and Commonwealth Scientific and Industrial Research Organisation, 2011). Prevailing winds are from the east, causing Tarawa and adjacent atolls to have coral dominant eastern windward reef coasts, and western leeward lagoons with reduced reef development (Paulay and Kerr, 2001). The tidal range is 1.1-1.3 m (Lelaurin, 2000).

During El-Niño periods, the prevailing wind and wave directions change from easterly to westerly (Solomon and Forbes, 1999), causing oscillations in beach profiles on Tarawa (Gillie, 1997). On Abaiang, during prevailing easterly winds, lagoonal longshore drift is predominantly from south to north, which reverses during El Niño conditions (Lelaurin, 2000).

Coral reef surveys of Abaiang show that windward sites close to St Joseph's College reef (Figure 1) are spur and groove hard coral reefs, with coralline algae and gastropods close to shore (Lovell, 2000). Percent cover surveys at the southern point of the main atoll island of Teiro (Figure 1) showed hard coral (44\%), coralline algae (30\%), Halimeda $(4 \%)$ and sand (21\%), with deeper reefs showing more abundant hard coral $(72 \%)$. Lagoonal reefs offshore of Wakeem (Figure 1) were characterized by inshore silty environments inhospitable to reefs, with little hard coral (15\%), macroalgae (8\%) and dominant sand and reef rock (81\%) (Lovell, 2000). The flora of Abaiang has not been as comprehensively studied as other Kiribati atolls (Thaman and Tye, 2015). Important components of the Abaiang flora are Cocos nucifera, Guettarda speciosa, Casuarinas, Morinda citrifolia, Scaevola sericea, Tournefortia argentea, Calophyllum inophyllum, Cordia subcordata, Pemphis acidula, Terminalia samoensis, Pisonia grandis, Clerodendrum inerme and introduced species (MISA, 2008).

\section{Sample Collection}

The main island of Abaiang atoll, Teiro, is $36.72 \mathrm{~km}$ long and up to $0.92 \mathrm{~km}$ wide (Office of Teberetitenti, 2012). Eight study sites were located from north to south along the shore of Teiro (Figure 1; Table 1), mostly on the lagoon shore and with comparative sites on the reef shore. Following Kiribati traditions, access was gained through the Island's Mayor and Town Officer, and granted by leaders of each community following explanation of study objectives. At each site (Figure 1), a topographic profile was surveyed, and samples were collected from upper, centre and lower levels, of each narrow beach. Elevation relative to MSL datum was determined using the high tide mark and adjusted using the Tarawa tide prediction (Bureau of Meteorology, 2015), following Bini et al. (2014). Distance along the profile was measured from the upper beach vegetation edge, and samples were taken at low tide from the undisturbed sand surface. At each sample point, 20 sub-samples spaced $10 \mathrm{~cm}$ apart were combined from each side of the surveyed profile.

Samples were preserved and stored separately in tightly sealed containers for export from Kiribati, gamma irradiated for biosecurity on entry to Australia, then oven dried at $50^{\circ} \mathrm{C}$ for 48 hours or longer when required. A well-mixed, split sub-sample of 30 to $50 \mathrm{~g}$ was taken from each sample for assessment of major metals, carbonate proportion, grain-sizes, roundness and constituent composition of the sediment. 
Table 1. Location of sampling sites Abaiang atoll, Kiribati. Sampling location denotes the distance from the upper beach vegetation edge.

\begin{tabular}{|c|c|c|c|c|c|c|}
\hline \multirow[b]{2}{*}{ Code } & \multirow[b]{2}{*}{ Site Name } & \multirow[b]{2}{*}{$\begin{array}{l}\text { Geographic } \\
\text { coordinates }\end{array}$} & \multirow[b]{2}{*}{$\begin{array}{l}\text { Offshore } \\
\text { type }\end{array}$} & \multicolumn{3}{|c|}{ Sampling location (m) } \\
\hline & & & & $\begin{array}{l}\text { Upper } \\
\text { beach }\end{array}$ & $\begin{array}{l}\text { Middle } \\
\text { beach }\end{array}$ & $\begin{array}{l}\text { Lower } \\
\text { beach }\end{array}$ \\
\hline A & Takarano & $\begin{array}{l}\text { N } 01^{\circ} 56.687 \\
\text { E } 172^{\circ} 55.281\end{array}$ & Lagoon & 2.84 & 7.74 & 12.24 \\
\hline B & Ubwanteman & $\begin{array}{l}\mathrm{N} 01^{\circ} 54.412 \\
\text { E } 172^{\circ} 57.263\end{array}$ & Lagoon & 1.8 & 6.0 & 9.4 \\
\hline $\mathrm{C}$ & $\begin{array}{l}\text { Wakeem Primary } \\
\text { School }\end{array}$ & $\begin{array}{l}\text { N } 01^{\circ} 52.746 \\
\text { E } 172^{\circ} 59.028\end{array}$ & Lagoon & 1.3 & 6.8 & 9.2 \\
\hline $\mathrm{D}$ & $\begin{array}{l}\text { St. Joseph's College } \\
\text { Reef }\end{array}$ & $\begin{array}{l}\text { N } 01^{\circ} 48.411 \\
\text { E } 173^{\circ} 02.238\end{array}$ & Reef & 2.0 & 9.0 & 14.0 \\
\hline $\mathrm{E}$ & $\begin{array}{l}\text { St. Joseph's College } \\
\text { Lagoon }\end{array}$ & $\begin{array}{l}\mathrm{N} 01^{\circ} 48.198 \\
\text { E } 173^{\circ} 02.060\end{array}$ & Lagoon & 2.2 & 7.2 & 9.7 \\
\hline $\mathrm{F}$ & Tanimaiaki Clinic & $\begin{array}{l}\text { N } 01^{\circ} 44.765 \\
\text { E } 173^{\circ} 02.266\end{array}$ & Lagoon & 7.5 & 12.0 & 18.0 \\
\hline G & Taniau KP Church & $\begin{array}{l}\text { N } 01^{\circ} 42.943 \\
\text { E } 173^{\circ} 00.438\end{array}$ & Lagoon & 0.8 & 8.8 & 16.8 \\
\hline $\mathrm{H}$ & Tebontebike & $\begin{array}{l}\text { N } 01^{\circ} 43.618 \\
\text { E } 172^{\circ} 59.379\end{array}$ & Reef & 3.0 & 8.9 & 14.0 \\
\hline
\end{tabular}

\section{Texture and Physical Properties}

Grain-size analysis allows the interpretation of processes active on a beach, and the sources of sediment. Methods followed Stoddart (1978), avoiding errors described by McManus (1988), with samples dry sieved through a cascade of sieves of $4,2,1,0.5,0.25,0.125,0.063 \mathrm{~mm}$. Physical size distribution parameters of mean grain-size, degree of skewness, degree of sorting and kurtosis were calculated using statistical methods, formulas and interpretations following Wentworth (1922), Folk (1954, 1966), and Folk and Ward (1957). Sorting indicates the spread of different sediment sizes around a central tendency, skewness shows any asymmetry in the spread such as a long tail of finer particles, and kurtosis is a ratio of the spreads of the tails and the centre of the distribution (McManus, 1988). Coarse sediment is associated with areas of stronger wave action, fine sediment suggests weak wave action, and poorly sorted sediment indicates quiet water processes and slow deposition (Stewart, 1958). Roundness was assessed visually from the bulk sample under a dissecting microscope (Powers, 1953), before sieving, using the six scale key of Shepard and Young (1961). Calcareous sediment derived from algae, coral and shell fragments is initially angular, or with protuberances in the case of foraminifera; with wave action the shapes become rounded or worn. The angled or round nature of sediment can show how long it has been subjected to wave action processes.

\section{Sand Composition}

The composition of the sediment was examined from sub-samples of all size fractions using a dissecting microscope at magnifications ranging from x6.7-40, and composition in classes of coral, molluscs, calcareous algae and foraminifera determined by comparison with reference sources (Folk and Robles, 1964; Falls and Textoris, 1971; Carpenter and Niem, 1998; BioInformatics, 2009; Glover and Taylor, 2001; Wilson, 2013; Yasukochi et al., 2014). 


\section{Geochemical Analysis}

For analysis of the geochemical composition of sediments, all glassware and containers were chemically cleaned with concentrated analytical reagent (AR) grade hydrochloric acid $(\mathrm{HCl})$ and concentrated $\mathrm{AR}$ nitric acid $\left(\mathrm{HNO}_{3}\right)$ before rinsing with distilled water. Bulk sediment samples of c. $250 \mathrm{~g}$ were dried at $50^{\circ} \mathrm{C}$ to constant mass $(<0.05 \%$ variation between weight measurements). A $3 \mathrm{~g}$ composite sub-sample of dry sediment was dissolved in $10 \mathrm{~mL}, 32 \mathrm{wt} \% \mathrm{AR} \mathrm{HCl}$ for calcium $(\mathrm{Ca})$, magnesium $(\mathrm{Mg})$ and sodium (Na) analysis. The reaction was allowed to continue for at least 15 minutes or more until reactions ceased. The solution then was made up to a volume of $100.0 \mathrm{~mL}$ in a volumetric flask.

Calcium, magnesium, and sodium concentrations were determined using a GBC ExplorAA atomic absorption spectrophotometer (AAS). Ca was analysed at $422.7 \mathrm{~nm}$ with nitrous oxide - acetylene flame. A calibration curve was generated using 0-5 ppm calcium standard solutions prepared from a 1,000 ppm AccuTrace ${ }^{\mathrm{TM}}$ Reference Standard. Samples were diluted by serial dilution to fit within the calibration range. Blanks, standards and test solutions for $\mathrm{Ca}$ analysis were prepared to have a final concentration of 2,000 ppm K $\mathrm{K}^{+}$, and $1 \% \mathrm{HNO}_{3} . \mathrm{Mg}$ was analysed at $285.2 \mathrm{~nm}$ with air-acetylene flame and 0-1 ppm magnesium standards prepared from a 1,000 ppm AccuTrace ${ }^{\mathrm{TM}}$ Reference Standard. Sodium was analysed at $589.0 \mathrm{~nm}$ with air-acetylene flame and 0-1.5 ppm sodium standard prepared from a 1,000 ppm AccuTrace ${ }^{\mathrm{TM}}$ Reference Standard.

To quantitatively determine the carbonate fraction of the sediment, the gravimetric acid dissolution method was adopted from Pilkey et al. (1967). A fresh $3 \mathrm{~g}$ sample of dry sediment was flooded with 20 to $30 \mathrm{~mL}$ of distilled water followed by the addition of three $3 \mathrm{~mL}$ aliquots of $32 \mathrm{wt} \% \mathrm{HCl}$. The solution was vacuum filtered through dried $1.2 \mu \mathrm{m}$ glass fibre filters (Micro analytix $47 \mathrm{~mm}$ MSGC) and dried to a constant weight $(<0.05 \%$ difference $)$ at $60^{\circ} \mathrm{C}$ on a clean watch glass. The colour of the dry non-carbonate fraction left over after carbonate dissolution was visually described using Munsell (2000) colour charts, and photographed.

\section{Statistical Analyses}

Significance testing was performed using a Student $\mathrm{t}$-test and analysis of variance (ANOVA). The ttest was used to determine differences in various properties of beach sand between two categories such as lagoon or reef sites. Reports of erosion on Abaiang are predominantly from lagoonal shores (MISA, 2008; Office of Teberetitenti, 2012). One-Way-ANOVA analysis was used to determine differences in sand composition across all study sites and a posteriori test, Tukey's procedure, was used to compare and classify similar and dissimilar sites. Data analysis was performed using Microsoft Excel 2013 and IBM SPSS 22.

\section{RESULTS}

All beaches were narrow, spanning 10-20 m between the littoral vegetation edge at the top of the beach, and the lower beach break in slope to offshore lagoonal flats of finer sediment (Figure 2, Table 1). 


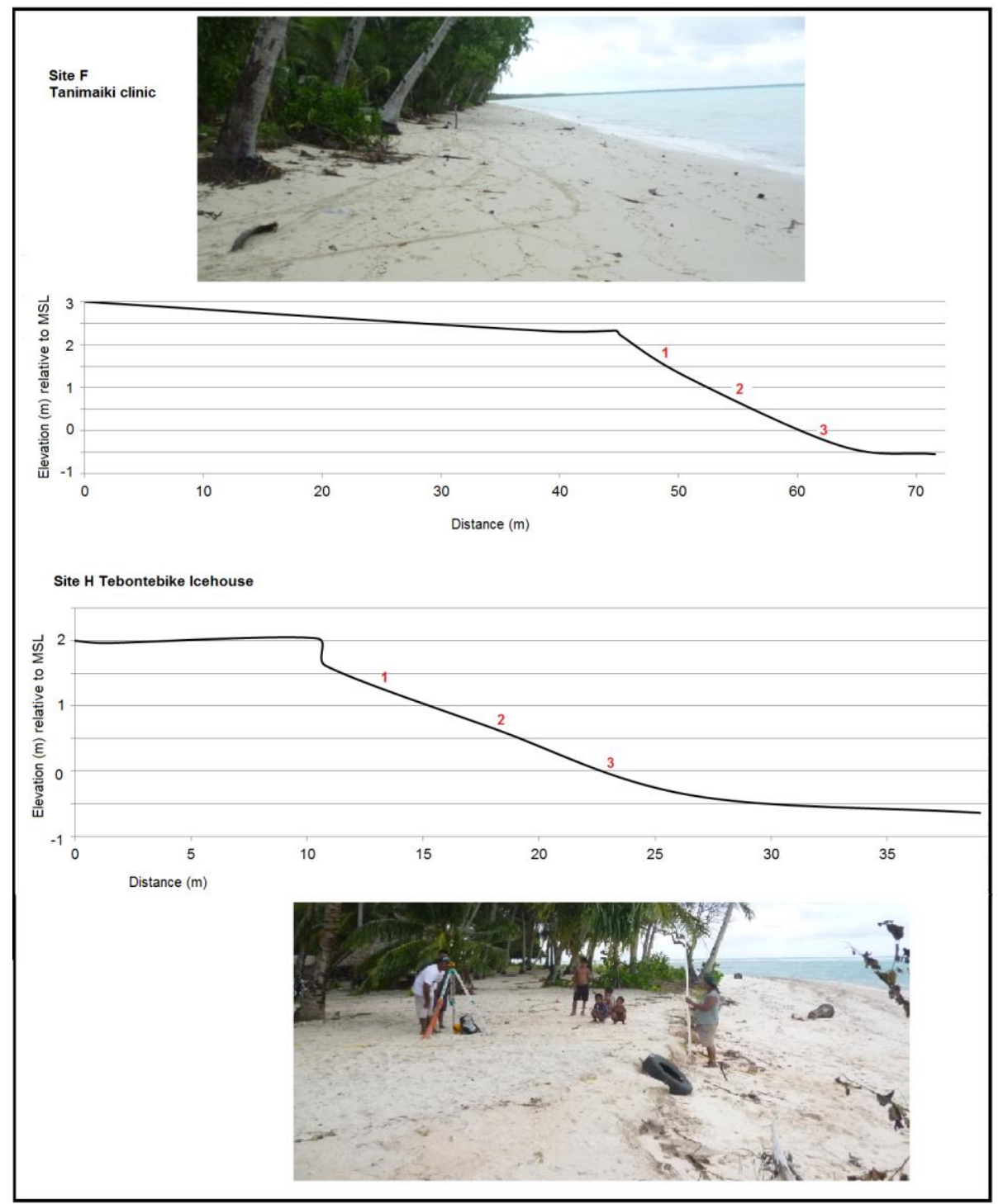

Figure 2. Representative beach profiles of a lagoon site (Tanimaiaki) and reef site (Tebontebike).

\section{Texture and Physical Properties}

The most frequent mean particle size class observed across all sampling sites was medium and coarse sand (mean $=0.58 \mathrm{~mm}, \mathrm{SD}=0.33$; Table 2). There was no significant difference between the mean grainsize values between the lagoonal and reef sites ( $\mathrm{t}$-test, $\mathrm{t}=0.102, \mathrm{df}=23, \mathrm{p}=0.920$ ). All sites showed an increase in the mean grain-size from the upper to lower beach (Table 2; Figure 3). Sites A, B, C and E displayed the most significant change in mean grain-size between the upper and lower beach ranging from $0.43-1.11 \mathrm{~mm}$. At sites D and F, the difference was only $0.16 \mathrm{~mm}$ and the remaining sites showed a mean grain-size difference of 0.25-0.32 mm between the upper and lower beach (Table 2; Figure 3).

All locations showed a similarity in the degree of symmetry of grain size distributions (symmetrical and fine skewed), and degree of sorting (moderately well sorted) (Table 2), except sites $\mathrm{C}$ and $\mathrm{E}$ which showed coarse skewed results particularly on the upper beach. Site A also showed upper beach coarse skewed results, which means there is a range of larger particles present. No significant difference in the degree of skewness was found between lagoon and reef sites. Upper beach site samples ranged from moderately well-sorted to moderately sorted, and both reef sites showed upper beach results of moderately 
Table 2. Results of beach sand physical properties for the beach samples from Abaiang, Kiribati: carbonate proportion, roundness, mean grain size with description, and statistics describing the distribution of particle sizes of sorting, skewness and kurtosis.

\begin{tabular}{llllll}
$\begin{array}{l}\text { Distance } \\
(\mathbf{m})\end{array}$ & Roundness & $\begin{array}{l}\text { Mean size } \\
(\mathbf{m m}) \text { and } \\
\text { description }\end{array}$ & $\begin{array}{l}\text { Sorting } \\
\text { (mod. means } \\
\text { moderately) }\end{array}$ & $\begin{array}{l}\text { Skewness } \\
\text { (v. means } \\
\text { very) }\end{array}$ & Kurtosis \\
\hline
\end{tabular}

\section{A: Takarano (Lagoon)}

$\begin{array}{llllll}2.84 & \text { Sub- rounded } & 0.24 \text { (fine) } & \text { mod. well sorted } & \text { coarse skewed } & \text { platykurtic } \\ 7.74 & \text { Sub- rounded } & 0.52 \text { (coarse) } & \text { poorly sorted } & \text { fine skewed } & \text { leptokurtic } \\ 12.24 & \text { Sub- rounded } & 0.85 \text { (coarse) } & \text { poorly sorted } & \text { fine skewed } & \text { leptokurtic }\end{array}$

\section{B: Ubwanteman (Lagoon)}

$\begin{array}{llllll}1.8 & \text { Sub- rounded } & 0.25 \text { (fine) } & \text { mod. well sorted } & \text { symmetrical } & \text { platykurtic } \\ 6.0 & \text { Sub- rounded } & 0.42 \text { (medium) } & \text { poorly sorted } & \text { symmetrical } & \text { leptokurtic } \\ 9.4 & \text { Sub- rounded } & 0.68 \text { (coarse) } & \text { mod. sorted } & \text { symmetrical } & \text { v. leptokurtic }\end{array}$

\section{C: Wakeem Primary School (Lagoon)}

$\begin{array}{llllll}1.3 & \text { Sub- rounded } & 0.39 \text { (medium) } & \text { poorly sorted } & \text { coarse skewed } & \text { v. leptokurtic } \\ 6.8 & \text { Sub- rounded } & 1.36(\mathrm{v} . \text { coarse) } & \text { poorly sorted } & \text { coarse skewed } & \text { platykurtic } \\ 9.2 & \text { Sub-rounded } & 1.54(\mathrm{v} . \text { coarse }) & \text { poorly sorted } & \text { fine skewed } & \text { platykurtic }\end{array}$

\section{D: St. Joseph's College (Reef)}

$\begin{array}{llllll}2.0 & \text { Well- rounded } & 0.39 \text { (medium) } & \text { mod. well sorted } & \text { symmetrical } & \text { leptokurtic } \\ 9.0 & \text { Sub- rounded } & 0.51 \text { (coarse) } & \text { mod. sorted } & \text { fine skewed } & \text { platykurtic } \\ 14.0 & \text { Rounded } & 0.55 \text { (coarse) } & \text { poorly sorted } & \text { symmetrical } & \text { platykurtic }\end{array}$

\section{E: St. Joseph's College (Lagoon)}

$\begin{array}{llllll}2.2 & \text { Rounded } & 0.22 \text { (fine) } & \text { mod. well sorted } & \text { coarse skewed } & \text { platykurtic } \\ 7.2 & \text { Sub- rounded } & 0.55(\text { coarse) } & \text { poorly sorted } & \text { coarse skewed } & \text { leptokurtic } \\ 9.7 & \text { Sub- rounded } & 1.05(\text { coarse }) & \text { mod. sorted } & \text { v. coarse skewed } & \text { mesokurtic }\end{array}$

\section{F: Tanimaiaki Clinic (Lagoon)}

$\begin{array}{llllll}7.5 & \text { Rounded } & 0.55 \text { (coarse) } & \text { mod. sorted } & \text { symmetrical } & \text { mesokurtic } \\ 12.0 & \text { Sub-rounded } & 0.52 \text { (coarse) } & \text { mod. well sorted } & \text { fine skewed } & \text { v. platykurtic } \\ 18.0 & \text { Sub-rounded } & 0.71 \text { (coarse) } & \text { mod. well sorted } & \text { symmetrical } & \text { mesokurtic }\end{array}$

\section{G: Taniau KP Church (Lagoon)}

$\begin{array}{llllll}0.8 & \text { Sub-rounded } & 0.35 \text { (medium) } & \text { mod. sorted } & \text { symmetrical } & \text { leptokurtic } \\ 8.8 & \text { Sub-rounded } & 0.32 \text { (medium) } & \text { poorly sorted } & \text { fine skewed } & \text { platykurtic } \\ 16.8 & \text { Sub-rounded } & 0.67 \text { (coarse) } & \text { poorly sorted } & \text { fine skewed } & \text { v. leptokurtic }\end{array}$

\section{H: Tebontebike (Reef)}

\begin{tabular}{llllll}
3.0 & Well-rounded & 0.35 (medium) & mod. well sorted & symmetrical & leptokurtic \\
8.9 & Well-rounded & 0.38 (medium) & mod. sorted & symmetrical & mesokurtic \\
14.0 & Well-rounded & 0.60 (coarse) & mod. well sorted & fine skewed & mesokurtic \\
\hline
\end{tabular}



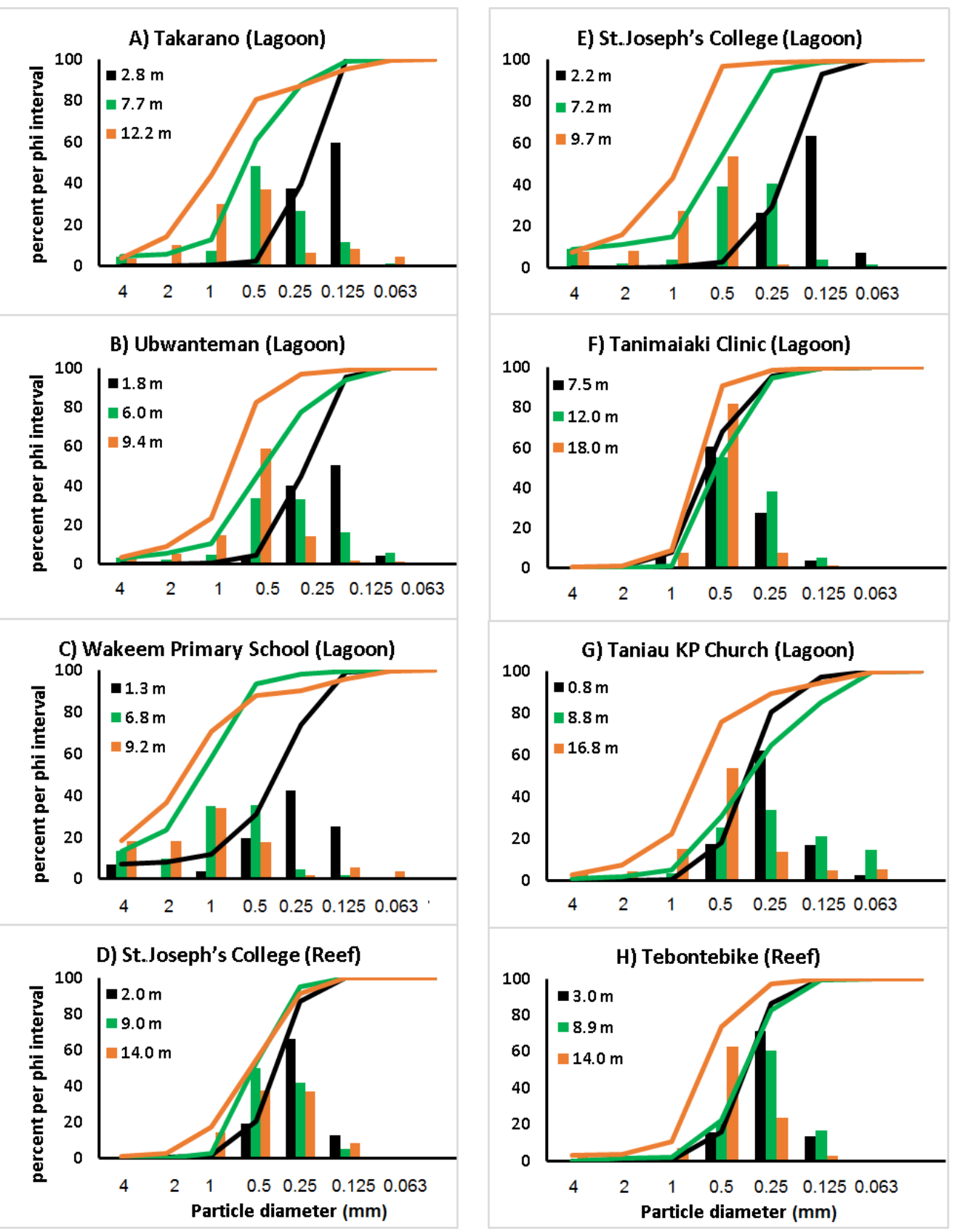

Figure 3. Beach sediment grain-size histograms and cumulative frequency curves, Abaiang, Kiribati. Sample distances are from the upper beach vegetation edge.

well sorted sediment (Table 2), which means the sediment sizes are quite similar. Both reef sites and two lagoon sites showed a leptokurtic distribution of sediment from upper beach samples, indicating a strongly peaked curve with good sorting in the centre of the grain size distribution (McManus, 1988).

A distinct difference in roundness was observed between reef and lagoon beach sediments (Table 2). Upper beach reef sites D and $\mathrm{H}$ both showed sediments that were well rounded. Site $\mathrm{H}$ in particular continued this character to lower beach areas. At the lagoon sites, all beach samples showed sub-rounded to rounded classifications (16 of 18). With the exception of the upper beach at sites $\mathrm{E}$ and $\mathrm{F}$, that showed 
rounded sediment, the upper, medium and lower beach sampling locations at lagoon sites (A, B, C, E, F and $\mathrm{G}$ ) generally showed a uniform sub-rounded sediment character.

\section{Sand Composition}

Average composition from all samples taken from each site and for all sites are graphed in Figure 4, and composition of samples across each beach are shown in Table 3. Of all study sites, the dominant sediment contributors were found to be corals ( $37 \% \pm 2.1 \mathrm{SD})$, molluscs $(30 \% \pm 2.6 \mathrm{SD})$, foraminifera $(12 \%$ $\pm 4.1 \mathrm{SD})$ and algae ( $20 \% \pm 0 \mathrm{SD}$ ) (Table 3$)$. There was no significant difference in the coral content across all 8 sites (One-Way-ANOVA, $\mathrm{f}=1.543, \mathrm{df}=7, \mathrm{p}=0.2228$ ). There was a significant difference in the coral content across samples from the lagoon and reef environments (t-test, $\mathrm{t}=2.344, \mathrm{df}=8.074, \mathrm{p}=0.047$ ). The lagoon beach sites showed approximately $5 \%$ higher composition of mean coral content relative to the reef beaches.

Mollusc shells contributed a mean of $32 \% \pm 4$ SD to the composition of lagoon beach sediments, and a mean of $25 \% \pm 7 \mathrm{SD}$ to the composition of lagoon beach sediments. A significant difference was found (ttest, $\mathrm{t}=3.765, \mathrm{df}=17, \mathrm{p}<0.002$ ), with the lagoon beaches having approximately $7 \%$ higher mollusc shells relative to reef beaches. Among all sites, there was no significant difference in the mollusc shell proportions (One-Way-ANOVA, $\mathrm{f}=2.7890, \mathrm{df}=7, \mathrm{p}=0.0423$ ).

Two common molluscs were of the Strombus genus, a gastropod with a short conical spire to the shell with rounded spikes (Figure 5A), and Wallucina fijiensis (Figure 5B), a bivalve with a thin, brittle shell that is widely distributed in the Indo-West Pacific (Glover and Taylor, 2001). Wallucina fijiensis has been reported as abundant on Tarawa (Paulay, 2000; CSIRO, 2016). Of the coarse particle sizes of 1.0-4.0 mm, mollusc and coral fragments were dominant, with no foraminifera. Sediment of 0.5-1.0 mm was also dominated by shell and coral fragments, with only low levels of foraminifera.

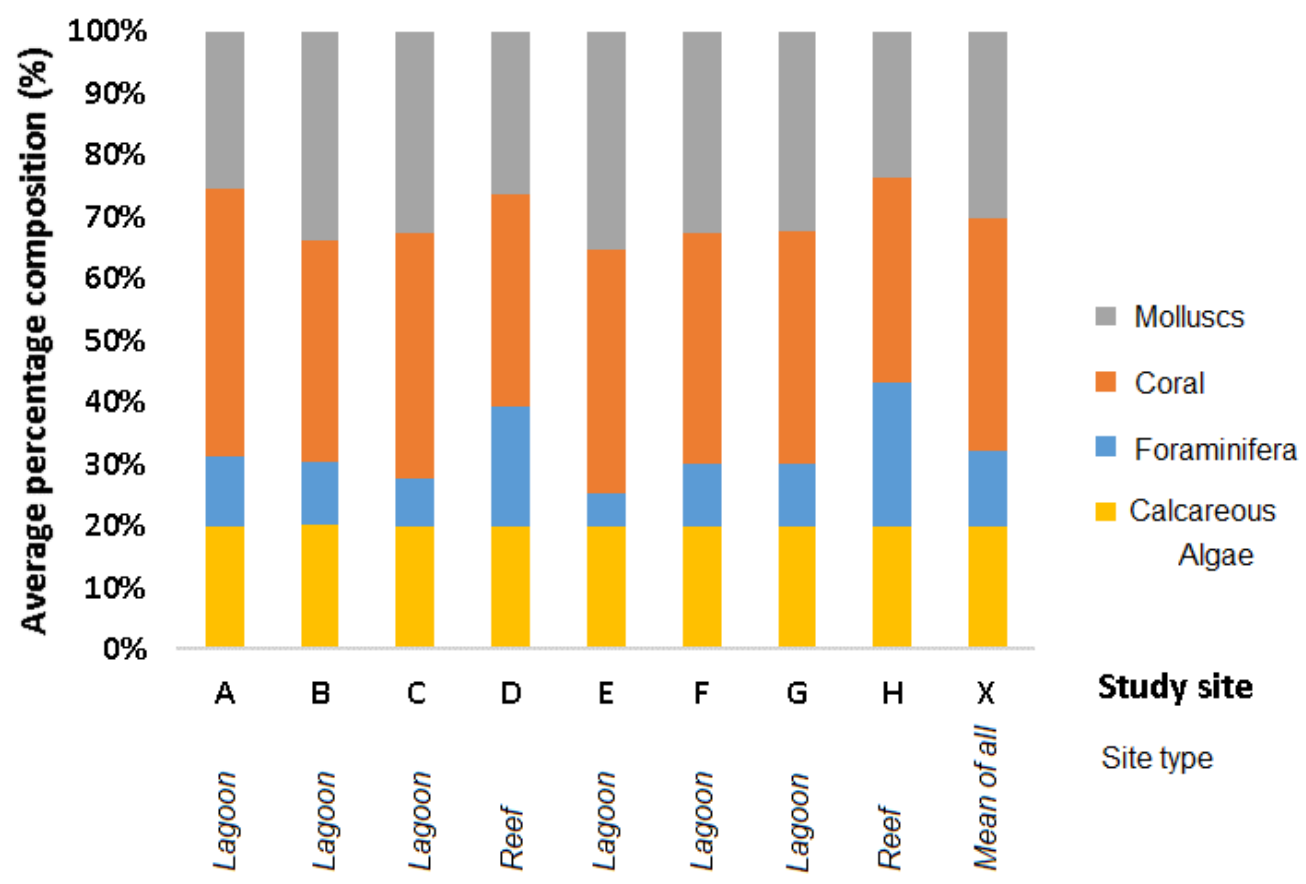

Figure 4. Beach sediment composition from lagoon and reef sites, Abaiang, Kiribati. Sites are located in Figure 1 and described in Table 1. Column X shows the average island beach sediment composition. 
Table 3. Results of composition (\% of sample) from each site (Figure 1), and position on the beach profile (Figure 2).

\begin{tabular}{|c|c|c|c|c|c|}
\hline Site & Sample location (m) & Foraminifera & Coral & Molluscs & Algae \\
\hline \multirow[t]{4}{*}{ A } & 2.84 & 5 & 45 & 30 & 20 \\
\hline & 7.74 & 15 & 43 & 22 & 20 \\
\hline & 12.24 & 14 & 42 & 24 & 20 \\
\hline & Mean $( \pm \mathrm{SD})$ & $11( \pm 5.5)$ & $43( \pm 1.5)$ & $25( \pm 4.2)$ & $20( \pm 0)$ \\
\hline \multirow[t]{4}{*}{ B } & 1.8 & 5 & 43 & 32 & 20 \\
\hline & 6.0 & 10 & 34 & 34 & 20 \\
\hline & 9.4 & 15 & 30 & 35 & 20 \\
\hline & Mean $( \pm \mathrm{SD})$ & $10( \pm 5.0)$ & $36( \pm 6.7)$ & $34( \pm 1.5)$ & $20( \pm 0)$ \\
\hline \multirow[t]{4}{*}{$\mathrm{C}$} & 1.3 & 10 & 39 & 31 & 20 \\
\hline & 6.8 & 10 & 36 & 34 & 20 \\
\hline & 9.2 & 3 & 44 & 33 & 20 \\
\hline & Mean $( \pm \mathrm{SD})$ & $8( \pm 4.0)$ & $40( \pm 4.0)$ & $33( \pm 1.5)$ & $20( \pm 0)$ \\
\hline \multirow[t]{4}{*}{$\mathrm{D}$} & 2.0 & 10 & 38 & 32 & 20 \\
\hline & 9.0 & 18 & 35 & 27 & 20 \\
\hline & 14.0 & 30 & 30 & 20 & 20 \\
\hline & Mean $( \pm \mathrm{SD})$ & $19( \pm 10.1)$ & $34( \pm 4.0)$ & $26( \pm 6.0)$ & $20( \pm 0)$ \\
\hline \multirow[t]{4}{*}{$\mathrm{E}$} & 2.2 & 5 & 38 & 37 & 20 \\
\hline & 7.2 & 8 & 39 & 33 & 20 \\
\hline & 9.7 & 3 & 41 & 36 & 20 \\
\hline & Mean $( \pm \mathrm{SD})$ & $5( \pm 2.5)$ & $39( \pm 1.5)$ & $35( \pm 2.1)$ & $20( \pm 0)$ \\
\hline \multirow[t]{4}{*}{$\mathrm{F}$} & 7.5 & 5 & 42 & 33 & 20 \\
\hline & 12.0 & 5 & 40 & 35 & 20 \\
\hline & 18.0 & 20 & 30 & 30 & 20 \\
\hline & Mean $( \pm \mathrm{SD})$ & $10( \pm 8.7)$ & $37( \pm 6.4)$ & $33( \pm 2.5)$ & $20( \pm 0)$ \\
\hline \multirow[t]{4}{*}{ G } & 0.8 & 10 & 40 & 30 & 20 \\
\hline & 8.8 & 15 & 35 & 30 & 20 \\
\hline & 16.8 & 5 & 38 & 37 & 20 \\
\hline & Mean $( \pm S D)$ & $10( \pm 5.0)$ & $47( \pm 2.5)$ & $42( \pm 4.0)$ & $20( \pm 0)$ \\
\hline \multirow[t]{5}{*}{$\mathrm{H}$} & 3.0 & 20 & 35 & 25 & 20 \\
\hline & 8.9 & 10 & 38 & 32 & 20 \\
\hline & 14.0 & 40 & 26 & 14 & 20 \\
\hline & Mean $( \pm \mathrm{SD})$ & $23( \pm 15.3)$ & $33( \pm 6.2)$ & $24( \pm 9.1)$ & $20( \pm 0)$ \\
\hline & Island Average $( \pm \mathrm{SD})$ & $12( \pm 4.1)$ & $37( \pm 2.1)$ & $30( \pm 2.6)$ & $20( \pm 0)$ \\
\hline
\end{tabular}



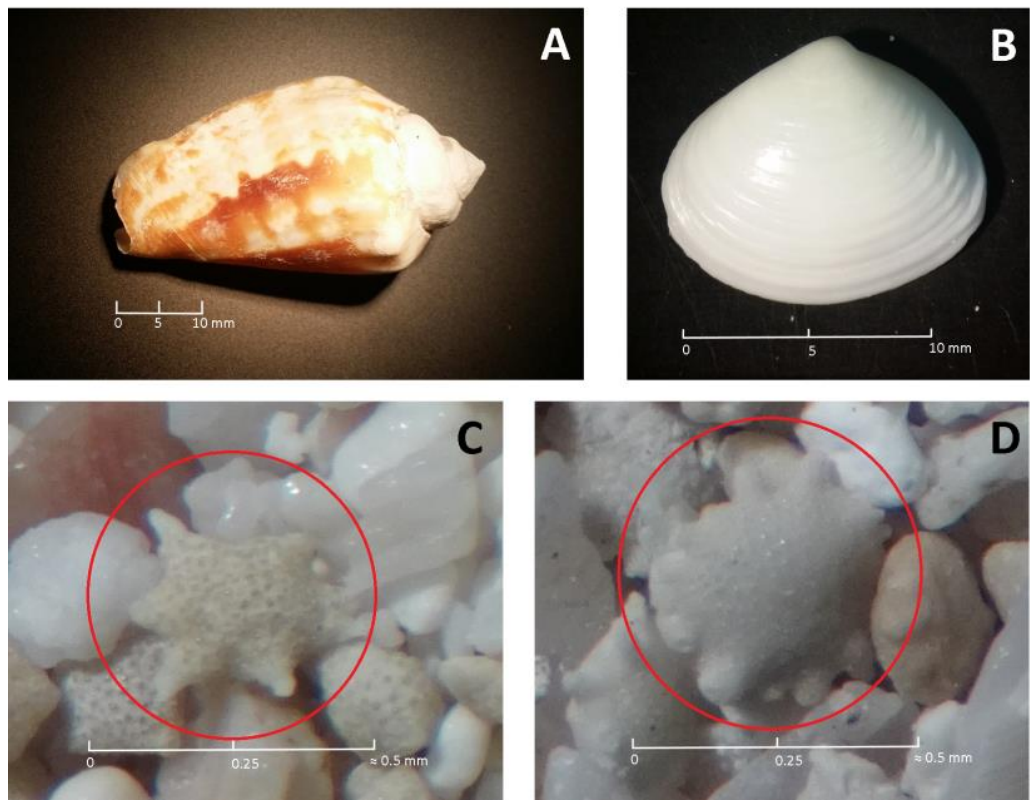

Figure 5. Beach sand constituents commonly found from beach sediment samples of Abaiang, Kiribati. A) Phylum Mollusca, genus Strombus shell, B) Phylum Mollusca, Wallucinia fijiensis, C) Phylum Foraminifera, genus Baculogypsina, D) Phylum Foraminifera, genus Calcarina.

The contribution of calcareous algae to Abaiang beach sand was more difficult to confirm owing to small fraction sizes, and the fragments having poorly distinguishable features relative to other contributors such as foraminifera, corals and shells (Figure 5). Many fragments examined resembled the non-skeletal grains or intraclasts, described from Oahu by Harney et al. (2000) as being mostly of algal origin. Halimeda calcareous algae disarticulates into the finest particles of all calcareous bioclasts (Perry et al., 2011), being less taphonomically durable relative to corals, shells and foraminifera (Ford and Kench, 2012), so more likely to break up in active processes, to form finer sands (Milliman, 1974).

Foraminifera showed the lowest relative abundance after coral fragments, mollusc- and algae-derived sediment (Figure 4). The highest relative abundance of foraminifera was found on reef beaches at low beach sampling zones (30 to 40\%) (Table 3). There was a significant difference in the foraminifera composition in the sediments of lagoon and reef beaches ( $\mathrm{t}$-test, $\mathrm{t}=4.301, \mathrm{df}=17, \mathrm{p}<0.001$ ), with reef beaches showing a mean of $12 \%$ higher foraminifera levels relative to lagoon beaches. Two common foraminifera occurring were Baculogypsina (Figure 5C) and Calcarina (Figure 5D).

\section{Geochemistry}

Gravimetric analysis of carbonate content in each of the sieve fractions indicated that all sands were carbonate dominant, with more than $99 \%$ of the sediment soluble in acid (Table 4). Calcium levels as determined using AAS analysis showed that beach sediments had a mean of $32.07 \% \pm 2.13$ SD calcium by mass, with a range of $29.13-34.80 \%$ mass ratio (Table 4). There was no significant difference in the mean calcium percentage between the lagoon and reef beach sediments ( $\mathrm{t}$-test, $\mathrm{t}=0.709$, $\mathrm{df}=6, \mathrm{p}=0.505$ ). Calcium can be present as calcium sulphate or calcium chloride as well as calcium carbonate, so geochemical analysis also determined calcium carbonate content, (Table 4), which showed a mean of $80.09 \% \pm 5.31 \mathrm{SD}$ of the sand of beach sites with range extending from 72.77 to $86.92 \%$ mass ratio. There was no significant difference in the calcium carbonate levels between the sediment of the lagoon and reef beaches ( $\mathrm{t}$-test, $\mathrm{t}=0.709, \mathrm{df}=6, \mathrm{p}=0.505)$. 
Table 4. Results of geochemistry analysis, and colour of the non-carbonate residue, from study beaches, Abaiang, Kiribati.

\begin{tabular}{|c|c|c|c|c|c|c|c|c|}
\hline Site & $\mathbf{A}$ & B & $\mathbf{C}$ & D & $\mathbf{E}$ & $\mathbf{F}$ & $\mathbf{G}$ & $\mathbf{H}$ \\
\hline Offshore type & Lagoon & Lagoon & Lagoon & Reef & Lagoon & Lagoon & Lagoon & Reef \\
\hline $\begin{array}{l}\text { Calcium } \\
\text { (\%mass) }\end{array}$ & 34.31 & 31.32 & 29.14 & 30.29 & 30.56 & 34.81 & 34.21 & 31.93 \\
\hline $\begin{array}{l}\mathrm{CaCO}_{3} \\
(\% \text { mass })\end{array}$ & 85.68 & 78.22 & 72.77 & 75.65 & 76.31 & 86.92 & 85.44 & 79.74 \\
\hline $\begin{array}{l}\text { Magnesium } \\
\text { (\% mass) }\end{array}$ & 1.36 & 1.48 & 1.37 & 1.86 & 1.33 & 0.98 & 1.12 & 1.55 \\
\hline $\begin{array}{l}\mathrm{MgCO}_{3} \\
(\% \text { mass })\end{array}$ & 4.73 & 5.13 & 4.75 & 6.45 & 4.62 & 3.39 & 3.88 & 5.38 \\
\hline $\begin{array}{l}\text { Sodium } \\
\text { (\% mass) }\end{array}$ & 0.57 & 0.53 & 0.43 & 0.48 & 0.48 & 0.52 & 0.65 & 0.39 \\
\hline $\begin{array}{l}\text { Acid soluble } \\
\text { (\% mass) }\end{array}$ & 99.51 & 99.80 & 99.45 & 99.92 & 99.45 & 99.78 & 99.77 & 99.79 \\
\hline $\begin{array}{l}\text { Acid insoluble } \\
(\% \text { mass })\end{array}$ & 0.49 & 0.20 & 0.55 & 0.08 & 0.55 & 0.22 & 0.23 & 0.21 \\
\hline $\begin{array}{l}\text { Non-carbonate } \\
\text { residue colour }\end{array}$ & $\begin{array}{l}10 \mathrm{YR} \\
(4 / 2)\end{array}$ & $\begin{array}{l}10 Y R \\
(4 / 3)\end{array}$ & $\begin{array}{l}10 Y R \\
(4 / 4)\end{array}$ & $\begin{array}{l}10 \mathrm{YR} \\
(8 / 3)\end{array}$ & $\begin{array}{l}10 \mathrm{YR} \\
(4 / 4)\end{array}$ & $\begin{array}{l}10 \mathrm{YR} \\
(5 / 3)\end{array}$ & $\begin{array}{l}10 \mathrm{YR} \\
(5 / 3)\end{array}$ & $\begin{array}{l}10 \mathrm{YR} \\
(7 / 4)\end{array}$ \\
\hline
\end{tabular}

Across the island, magnesium was found to constitute $1.38 \% \pm 0.27 \mathrm{SD}$ of the sediments, equating to $4.79 \% \pm 0.93 \mathrm{SD}$ of the total mass as magnesium carbonate (Table 4). There was a significant difference between the lagoon and reef beaches in the magnesium composition of the sediment $(\mathrm{t}$-test, $\mathrm{t}=2.753, \mathrm{df}=$ $6, p=0.033$ ). Reef beaches on average had about $0.43 \%$ more magnesium by weight than lagoon sites. There was a significant difference in the magnesium carbonate composition of the sediment between lagoon and reef beaches ( $\mathrm{t}$-test, $\mathrm{t}=2.752 \mathrm{df}=6, \mathrm{p}=0.033$ ). On average, reef sites had about $1.50 \%$ more magnesium carbonate by weight than lagoon sites. Overall, $84.88 \% \pm 4.78 \mathrm{SD}$ of sediment by mass was accounted for as the calcium and magnesium carbonates (Table 4). Sodium was found to constitute $0.51 \%$ \pm 0.08 SD by weight of the sediments. The remainder was composed of other acid soluble compounds, while $<1 \%$ of the sediment was insoluble.

This small amount of insoluble material $(<1 \%)$ was found in sand samples from all beaches (Table 4$)$, with a mean of the weight of measured samples of $0.32 \% \pm 0.18 \mathrm{SD}$. The highest mass of insoluble material was observed in lagoon sites $\mathrm{A}, \mathrm{C}$ and $\mathrm{E}$, with an average insoluble content of $0.53 \% \pm 0.04$ of the total mass. The reef site (D) at St. Joseph's College had the lowest insoluble non-carbonate residue of $0.08 \%$ by weight. There was no significant statistical difference in the insoluble fraction of the sediment $(\mathrm{t}$-test, $\mathrm{t}=$ $1.720, \mathrm{df}=6, \mathrm{p}=0.136$ ) between lagoon-facing and seaward reef-facing beaches. Results from colour of the insoluble residue are shown in Table 4, all of Hue $10 \mathrm{YR}$, but with darker values found from the lagoon sites and lighter values found from the reef sites, the photographs in the last row showing the reef sites of $\mathrm{D}$ and $\mathrm{H}$ to have paler browns than the lagoon sites, particularly lagoon sites of the northern part of the atoll.

\section{DISCUSSION}

Carbonate sand was the only sediment classification found in all samples collected from Abaiang lagoon and reef beaches (Table 2, Table 4), with sources from corals, mollusc shells, and foraminifera (Figure 4, Table 3). Beach composition is discussed first because the texture and geochemistry results likely rely on the biogenic sources of the different components of the sand, such as proportions of coral or 
foraminifera. Most atoll reef islands in the Pacific show foraminifera dominance (Perry et al., 2011; Ellison et al., 2017), but all Abaiang beaches were coral-dominant (Figure 4). Surface sediments of reef islands in Fiji also showed coral-dominance (McKoy et al., 2010), and on Tarawa, Ebrahim (2000) also found coral dominance in beach sand, with higher foraminifera (c. 37\%), and lower proportions of molluscs (c. 15\%) and Halimeda (c. 4\%) relative to results from Abaiang (Table 3).

While coral was the highest contributor to Abaiang beach sand at all sites, there was an unexpected significant difference between coral content at reef sites and lagoon sites, with higher levels of coral at lagoon sites. This was unexpected because of higher coral proportions reported from offshore surveys on windward sites relative to lagoon sites (Lovell, 2000), and may be derived from wind-driven waves and currents being responsible for the active transport of reef-derived materials to the lagoons (Yamano et al., 2002). Coral fragments have high taphonomic durability to mechanical destruction in quiet water conditions (Scoffin, 1992). While the sediment contribution of foraminifera was lower than found at Fongafale Island of Funafuti Atoll, Tuvalu (Collen and Garton, 2004), with an average for Abaiang sites of 12\% (Figure 4), it also made a significantly greater contribution at reef sites, increasing to a mean of $20 \%$ and a maximum of $40 \%$ (Table 3). By contrast, little difference ( $<5 \%$ variation) was found in proportions of coral, foraminifera and molluscs on ocean and lagoon facing beaches on Tarawa (Ebrahim, 2000), with less than $5 \%$ difference in results. Reef environments fringe Abaiang (Figure 1), with closer proximity and higher diversity and productivity (Paulay and Kerr, 2001) at windward sites relative to leeward reef sites. The significant difference of lower coral proportions in reef beach sediments may be owing to dilution by abundant foraminifera supply at reef sites, with large foraminifera presence described as reflecting coral reef vitality in low nutrient marine environments (Hallock, 2000). Foraminiferal abundance may fluctuate with wind conditions, with direct winds tending to sweep individuals off the substratum (Fujita et al., 2009). No evidence was found in variations of corals, mollusc and foraminifera proportions between the lagoonal sites, likely showing effective lagoonal circulation.

Abaiang results showed a lower contribution of foraminifera to beach sand (Table 3) relative to other Pacific atolls (Collen and Garton, 2004; Yamano et al., 2005; Perry et al., 2011; Ellison et al., 2017). The identified foraminifera of genus Baculogypsina (Figure 5C) and Calcarina (Figure 5D) are commonly found on Tarawa (Smith and Biribo, 1995), where they are abundant contributors to beach sediments (Ebrahim, 2000). On the nearest atoll to Abaiang, extensive sampling of sediments around Tarawa found living foraminifera only at ocean-facing sites (Ebrahim, 2000), with the well-preserved nature of ocean beach foraminifera tests indicating close proximity to their source.

Shell contributors to Tarawa sand have not been identified before (Smith and Biribo, 1995). The identified mollusc genus Strombus (Figure 5A) lives on sandy areas of patch reefs, commonly found near coastlines in depths ranging from 3 to $30 \mathrm{~m}$ (Brownell, 1977; Tewfik and Guzman, 2003), and gastropods such as Strombus are common in nearshore lagoon waters on Tarawa (Thomas, 2001). These habitat preferences may explain the significantly higher mollusc shell composition on lagoon beaches relative to reef-facing beaches.

Halimeda is a major contributor of fine-grained lagoon sediment on nearby Tarawa (Weber and Woodhead, 1972; Smith and Biribo, 1995), and it is widespread on Abaiang (Lovell, 2000). Halimeda segments have low resistance to taphonomic breakdown, owing to flakes that are easily fragmented (Scoffin, 1992). Nearshore carbonate sediments with Halimeda, molluscs and foraminifera content, were shown to have chemical compositions of $\mathrm{MgCO}_{3}$ and $\mathrm{CaCO}_{3}$ (Chave, 1954; Böhm, 1973) in the same ranges as our results (Table 4). Lower levels of Halimeda contribution to beach sand is a recognised trend across Pacific atolls (Yamano et al., 2005; Perry et al., 2011), relative to Caribbean atolls which show dominance in beach composition by Halimeda (Perry et al., 2011).

These biogenic carbonate sediment sources were confirmed from geochemical analysis results, with over $99 \%$ of all beach sand samples dissolving in $\mathrm{HCl}$ (Table 4), and with sands comprised of $85 \%$ of carbonates of calcium and magnesium (Table 4). The contribution of different geochemical compounds to carbonate beach sand has been little analysed previously, and results (Table 4) allow identification of the different carbonates. Biologically, magnesium is essential to tissue and skeleton formation in lime-secreting marine organisms such as molluscs and foraminifera (Chave, 1954), and magnesium is present in both 
aragonite and calcite mineralogies of carbonate sand (Falls and Textoris, 1972; Halley, 2000). While corals and shells have a high composition of calcium carbonate, often corals and Mollusc shells have much higher magnesium carbonate content than calcite (Weber and Woodhead, 1972). Magnesium and magnesium carbonate content was found to be higher at reef sites relative to lagoon sites, where foraminifera content in sediment was double that of lagoon sites (Figure 4, Table 3). Magnesium carbonate is present in reef foraminifera (Ponder and Glendinning, 1974; Morris et al., 2003), likely causing the higher levels found of magnesium on reef-facing sites. Magnesium carbonate levels of Abaiang beach sand of 4.8\% (Table 4) were higher than contents found in reef flat sediments offshore of Viti Levu (Morris et al., 2003), likely owing to higher foraminiferal composition (Table 3).

The non-carbonate residue appeared as a high-volume floc of clay-like particles, which after filtration showed a low mass of $<1 \%$ of the sediment (Table 4), similar to proportions found on Tarawa (Forbes and Hosoi, 1995; Forbes and Solomon, 1997; Ellison et al., 2017). The colours showed consistent variation between reef and lagoon sites, between which beach composition showed a significant difference in abundance levels of coral, molluscs and foraminifera (Figure 4; Table 3). This very minor non-carbonate material could consist of siliceous material from sponge skeletons, or unusual compounds such as magnetite crystals from chitons (Smith and Collen, 2004), which may dissolve in acid (Salmimies et al., 2011) but only after a far longer exposure than our analyses. The residue may also have a contribution from insoluble proteins, as reaction between some protein molecules and $\mathrm{HCl}$ is known to be extremely slow, and requires several days for a complete digestion to occur (Armstrong and Hollyman, 2015). This study, in combining geochemical, texture and composition analysis, shows that it is from within the biogenic sand, not from a different particle such as pumice.

Sand grain-size results from Abaiang of predominantly medium to coarse sand were similar to results from reef flat and island sediments of reef cays of Fiji (McKoy et al., 2010). Results also showed beach sediment to be finer on the upper beaches relative to lower beaches (Table 2; Figure 3), as shown from both Tepuka Island, Funafuti (Kench et al., 2014) and a lagoon beach of North Tarawa (Ellison et al., 2017). Upper beach sand samples showed better sorting relative to lower beach samples, with the least trend at site C. During normal conditions of prevailing winds from the east, currents through the barrier reef passage from the west arrive at this location on the Teiro lagoon shore (Lelaurin, 2000), with coarser and more poorly sorted sand at site $\mathrm{C}$ relative to the other lagoonal sites (Table 2). Micro-tidal tropical beaches are wave dominated (Short, 1999), and at low tide on lagoonal shores wave energy is low with patchy water depths across extensive lagoonal offshore flats. During fieldwork it was observed on lagoonal beaches that at high tide, waves break on the lower beach and wave swash moves the fines further up the beach profile, likely leaving coarse textures at the base of the beach. This interpretation is supported by the sediment rounding results (Table 2), where sites that showed any trend across the narrow beaches (Figure 2) showed more rounded sediment at the upper beach, indicating attrition processes from wave jostling of sediment.

At low tide on reef beaches, wave action remains outside the reef, while at high tide strong wave action occurs directly on the beach as the reef is overtopped. This brings mixing and high transport capacity across reef platforms with waves able to move sediment for c. 50\% of the time (McKoy et al., 2010). Ocean facing beaches on Tarawa are described as having constant, high-energy wave action (Weber and Woodhead, 1972), but at low tide wave action does not traverse the reef, so does not contact the beach. Such upper beach wave action explains the exceptionally well sorted grain-size distributions at reef sites (Table 2; McManus, 1988), along with rounded sediment properties (Table 2). Well sorted sediment can indicate consistency of wave action processes, which occurs during high tide conditions on these beaches, and rounding is also indicative of stronger wave action attrition processes.

There was a lack of fine sediment of silt or clay (diameter $<0.063 \mathrm{~mm}$ ) (Table 2, Figure 3 ) at all beaches sampled. This may be attributed to taphomomic sediment breakdown through calcium carbonate dissolution, which for reef sediments is not only high for smaller size fractions (Scoffin, 1992), but can be even higher where freshwater mixes with normally supersaturated surface seawater (Andersson and Gledhill, 2013). Abaiang, as indicated by adjacent Tarawa, normally has a high annual rainfall of over 2,000 mm. High carbonate fraction in the sediment (Table 4), slightly acidic rain water (Galloway et al., 1982; Nagamoto et al., 1990) and freshwater lens outflow at low tide could cause carbonate dissolution of fine particles from 
the beach. This would not affect sub-tidal waters, such as in the Tarawa lagoon where finer fractions are common (Weber and Woodhead, 1972; Smith and Biribo, 1995), with shallow marine water rarely falling below pH 7 or 8 (Milliman, 1974), being buffered by carbonate and sulphate species.

Sediment supply to beaches on Tawara has been reduced in the last few decades by inappropriate coastal protection and closure of lagoon passages by causeways (Forbes and Hosai, 1995; Duvat, 2013). This has contributed to a vicious cycle of use of beach sediment to raise people's plots and houses, causing destabilisation of the coast (Duvat, 2013). On Abaiang, population density is far lower and only one causeway has been constructed, leading to blockage of sand supply to northern beaches (Webb, 2006), resulting in ongoing shoreline erosion (MISA, 2008). This study shows that the sources of sediment to these beaches is carbonate sand derived from coral reefs, and lagoon benthic habitats such as seagrass beds with calcareous algae and molluscs. Beach sand supplies can be maintained by ensuring the health of these ecosystems, also preventing disruptions to sediment movement along the shoreline.

\section{CONCLUSIONS}

Beach sand properties and composition vary around Abaiang atoll, with significant differences in biogenic sources, such as coral, molluscs, and foraminifera, on reef beaches relative to lagoon beaches. Beach composition consistently showed differences to most other Pacific atolls studied, with a relatively low proportion of foraminifera, and relatively high domination by coral fragments. Coral dominance on lagoon facing-beaches indicates the need to maintain near shore processes of sediment transport that on modified atolls may have been blocked by the construction of causeways between atoll islands, as has occurred on Tarawa (Ebrahim, 2000).

Carbonate sediment sources found in this study on Abaiang beaches are reliant on productive ecosystems, and following human impacts supply can "turn off" particularly with changes in water quality such as eutrophication from sewage runoff, and loss of grazers and substrate eroders (Perry et al., 2011). Pollution in lagoon waters as has occurred on Tarawa can reduce foraminifera presence (Ebrahim, 2000), and while bioerosion can reduce abundance of coral fragments, there has been very limited study in the Pacific islands (Perry and Harborne, 2016). Coral bleaching can impact the productivity of reefs (HoeghGuldberg et al., 2007), compromising photosynthesis, calcification and reproduction (Baker et al., 2008), which may also reduce sediment supplies to beaches.

Abaiang is a pristine atoll relative to others which have a range of human impacts, such as Tarawa, Majuro and Palmyra. The importance of management to reduce potential impacts on biogenic sediment supplies in future are indicated from more impacted locations. Studies have found that local human-induced stress reduces coral bleaching resistance (Carilli et al., 2012), Some molluscs are highly sensitive to change in climatic conditions and anthropogenic activities that directly reduce recruitment success (Beukema and Dekker, 2005), which may result in a decline of sediment supply. Benthic foraminifera have been shown to be sensitive to anthropogenic pollution and limited water circulation (Ebrahim, 2000), particularly nutrient loading (Fujita et al., 2009; Fujita et al., 2014).

Sea level rise has been identified as the greatest threat to human habitability of the low lying Pacific islands (Church et al., 2013; Duvat et al., 2013). Atoll islands can persist, with creative adaptation pathways and planning (Kench et al., 2018). Continued supply of sediment can allow reef islands to morphologically adjust to changing environmental conditions (McKoy et al., 2010), and anthropogenic impacts such as trampling and anchor damage to nearshore habitats can reduce sediment supply, leading to beach erosion and threats to island communities and infrastructure. Beach rehabilitation can reduce erosion (Ellison et al., 2015), through reduction of human impacts that exacerbate erosion or damage sediment supply (Ebrahim, 2000), and use of ecosystem-based adaptation such as vegetation planting of littoral trees and vines (Ellison, 2018). Increased capacity for condition assessment, monitoring and management of coral reef and benthic lagoon habitats are direct preventative measures to prevent beach erosion. 


\section{ACKNOWLEDGMENTS}

This study was funded by the SPREP-USAID Climate Change Adaptation Project. The authors are grateful to Ratita Bebe, Arawaia Moiwa, and George Taoaba of the Kiribati Government who facilitated fieldwork. The authors thank two anonymous reviewers, and the Editor Marguerite Toscano, who provided comments that allowed improvements to the paper.

\section{REFERENCES}

Andersson, A. J., and D. Gledhill. 2013. Ocean Acidification and Coral Reefs: Effects on Breakdown, Dissolution, and Net Ecosystem Calcification. Annual Review of Marine Science, 5:321-348.

Armstrong, J., and K. Hollyman. 2015. General, Organic, and Biochemistry: An Applied Approach. 2 ed. Melbourne: CT Cengage Learning.

Australian Bureau of Meteorology, and Commonwealth Scientific and Industrial Research Organisation. 2011. Climate Change in the Pacific: Scientific Assessment and New Research Volume 1: Regional Overview. Melbourne: ABM and CSIRO.

Baker, A. C., P. W. Glynn, B. and Riegl, B., 2008. Climate Change and Coral Reef Bleaching: An Ecological Assessment of Long-Term Impacts, Recovery Trends and Future Outlook. Estuarine, Coastal and Shelf Science, 80(4), 435-471.

Beukema, J., and R. Dekker. 2005. Decline of Recruitment Success in Cockles and Other Bivalves in the Wadden Sea: Possible Role of Climate Change, Predation on Postlarvae and Fisheries. Marine Ecology Progress Series, 287:149-167.

Bini, M., I. Isola, M. Pappalardo, A. Ribolini, M. Favalli, L. Ragaini, L. and G. Zanchetta. 2014. Abrasive Notches along the Atlantic Patagonian Coast and their Potential Use as Sea Level Markers: The Case of Puerto Deseado (Santa Cruz, Argentina). Earth Surface Processes and Landforms, 39(11):15501558.

BioInformatics. 2009. Marine Species Identification Portal. http://species-identification.org/about.php [accessed 15 August 2015].

Böhm, E. 1973. Coral Reef Project-Papers in Memory of Dr. Thomas F. Goreau. 7. Studies on the Mineral Content of Calcareous Algae. Bulletin of Marine Science, 23:177-190.

Brownell, W. N. 1977. Reproduction, Laboratory Culture, and Growth of Strombus gigas, S. costatus and S. pugilus in Los Roques, Venezuela. Bulletin of Marine Science 27:668-680.

Bureau of Meteorology. 2015. Tarawa (Betio) Kiribati Times and Heights of High and Low Waters. Adelaide, Bureau of Meteorology, Commonwealth of Australia.

Carpenter, K., and V. Niem. 1998. The Living Marine Resources of the Western Central Pacific. v. 1: Seaweeds, Corals, Bivalves and Gastropods. FAO Species Identification Guide for Fisheries Purposes, 1:1-686.

Carilli, J., Donner, S. D., and A. C. Hartmann. 2012. Historical Temperature Variability Affects Coral Response to Heat Stress. PLoS One, 7(3): e34418. doi:10.1371/ journal.pone.0034418.

Chave, K. E. 1954. Aspects of the Biogeochemistry of Magnesium 1. Calcareous Marine Organisms. Journal of Geology, 62:266-283.

Church, J. A., P. U. Clark, A. Cazenave, J. M. Gregory, S. Jevrejeva, A. Levermann, M. A. Merrifield, G. A. Milne, R. S. Nerem, P. D. Nunn, A. J. Payne, W. T. Pfeffer, D. Stammer, and A. S. Unnikrishnan. 2013. "Sea Level Change". In Climate Change 2013: The Physical Science Basis, eds. T. F. Stocker, D. Qin, G. -K. Plattner, M. Tignor, S. K. Allen, J. Boschung, A. Nauels, Y. Xia, V. Bex, and P. M. Midgley, pp. 1137-1216. Contribution of Working Group I to the Fifth Assessment Report of the Intergovernmental Panel on Climate Change. Cambridge, United Kingdom and New York, NY, USA, Cambridge University Press.

Collen, J. D., and D. W. Garton. 2004. Larger Foraminifera and Sedimentation around Fongafale Island, Funafuti Atoll, Tuvalu. Coral Reefs, 23:445-454. 
Collen, J. D., D. W. Garton, and J. P. A. Gardner. 2009. Shoreline Changes and Sediment Redistribution at Palmyra Atoll (Equatorial Pacific Ocean): 1874-Present. Journal of Coastal Research, 25(3):711722.

[CSIRO] Commonwealth Scientific and Industrial Research Organisation. 2016. Australian Faunal Directory $C A A B$ taxon report: Wallucina fijensis (Smith, 1885) http://www.marine.csiro.au/caabsearch/caab search.caab report?spcode=23305016 [Accessed 25 August 2015].

Davies, J. L., and J. P. Hudson. 1987. Differential Supply and Longshore Transport as Determinants of Sediment Distribution on the North Coast of Tasmania. Marine Geology, 77(3-4):233-245.

Donner. S. 2013. Sea Level Rise and the Ongoing Battle of Tarawa. Eos, 93:169-176.

Dickinson, W. R. 2014. Beach Ridges as Favored Locales for Human Settlement on Pacific Islands. Geoarchaeology, 29(3):249-267.

Duvat, V. 2013. Coastal Protection Structures in Tarawa Atoll, Republic of Kiribati. Sustainability Science, 8:363-379.

Duvat, V., A. Magnan, and F. Pouget. 2013. Exposure of Atoll Population to Coastal Erosion and Flooding: a South Tarawa Assessment, Kiribati. Sustainability Science, 8:423-440.

Ebrahim, M. T. 2000. "Impact of Anthropogenic Environmental Change on Larger Foraminifera". In Environmental Micropaleontology, ed. R. E. Martin, pp 105-119. New York: Klewer Academic/Plenum Publishers.

Edwards, A. C., R. L. Hoz, J. U. Fucugauchi, A. S. Fortanel, E. M. Garza, and R. L. S. Cruz. 2005. Geochemical Distribution Patterns of Sediments in an Active Continental Shelf in Southern Mexico. Continental Shelf Research, 25:521-537

Ellison, J., P. Anderson P., and V. Jungblut. 2015. Coastal Ecosystem based Rehabilitation Guide. Apia, Samoa: Secretariat of the Pacific Regional Environment Program.

Ellison, J. C., 2018. "Pacific Island Beaches: Values, Threats and Rehabilitation". In Beach Management Tools - Concepts, Methodologies and Case Studies, eds. C. M. Botero, O. Cervantes, and C. W. Finkl, pp. 679-700. Cham, Switzerland: Springer International Publishing.

Ellison, J. C., A. Mosley, and M. Helman. 2017. Assessing Atoll Shoreline Condition to Guide Community Management. Ecological Indicators, 75:321-30.

Falls, D. L., and D. A. Textoris. 1972. Size, Grain Type and Mineralogical Relationships in Recent Marine Calcareous Beach Sands. Sedimentary Geology 7:89-102.

Friedman, G. M. 1968. Geology and Geochemistry of Reefs, Carbonate Sediments, and Waters, Gulf of Aqaba (Elat), Red Sea. Journal of Sedimentary Research, 38(3):895-919.

Folk, R. L. 1954. The Distinction between Grain Size and Mineral Composition in Sedimentary-Rock Nomenclature. Journal of Geology, 62:344-359.

Folk, R. L. 1966. A Review of Grain Size Parameters. Sedimentology, 6:73-93.

Folk, R. L. and R. Robles. 1964. Carbonate Sands of Isla Perez, Alacran Reef Complex, Yucatán. Journal of Geology, 72:255-292.

Folk, R. L. and W. C. Ward. 1957. Brazos River Bar: a Study in the Significance of Grain Size Parameters. Journal of Sedimentary Research, 27:3-27.

Forbes, D. L., and Y. Hosoi. 1995. Coastal Erosion in South Tarawa, Kiribati. South Pacific Applied Geoscience Commission, Suva.

Forbes. D., and S. Solomon. 1997. Approaches to Vulnerability Assessment on Pacific Island Coasts: Examples from Southeast Viti Levu (Fiji) and South Tarawa (Kiribati). SOPAC Miscellaneous Report, 277:1-21.

Ford, M. R., and P. S. Kench. 2012. The Durability of Bioclastic Sediments and Implications for Coral Reef Deposit Formation. Sedimentology, 59(3):830-842.

Fujita. K., Y. Osawa, H. Kayanne, Y. Ide and H. Yamano. 2009. Distribution and Sediment Production of Large Benthic Foraminifers on Reef flats of the Majuro Atoll, Marshall Islands. Coral Reefs, 28:2945 . 
Fujita, K., S. Nagamine, Y. Ide, Y. Umezawa, T. Hosono, H. Kayanne and H. Yamano. 2014. Distribution of Large Benthic Foraminifers around a Populated Reef Island: Fongafale Island, Funafuti Atoll, Tuvalu. Marine Micropaleontology, 113:1-9.

Galloway, J. N., G. E. Likens, W. C. Keene, and J. M. Miller. 1982. The Composition of Precipitation in Remote Areas of the World. Journal of Geophysical Research, 87:8771-8786.

Gillie, R. D. 1997. Causes of Coastal Erosion in Pacific Island Nations. Journal of Coastal Research, 24:173-204.

Gischler, E. 1994. Sedimentation on Three Caribbean Atolls: Glovers Reef, Lighthouse Reef and Turneffe Islands, Belize. Facies, 31(1): 243-254.

Glover, E. A., and J. D. Taylor. 2001. Systematic Revision of Australian and Indo-Pacific Lucinidae (Mollusca: Bivalvia): Pillucina, Wallucina and Descriptions of Two New Genera and Four New Species. Records of the Australian Museum, 53:263-292.

Goldberg, W. 2016. Atolls of the World: Revisiting the Original Checklist. Atoll Research Bulletin, 610:147.

Halley, R. B. 2000. "11 Things a Geologist Thinks an Engineer Should Know about Carbonate Beaches". In Carbonate Beaches 2000, ed. O. T. Magoon, L. L. Robbins and L. Ewing L, pp 1-14. Reston VA: American Society of Civil Engineers.

Hallock, P. 2000. "Larger Foraminifera as Indicators of Coral Reef Vitality". In Environmental Micropaleontology. ed. R. E. Martin, pp. 121-150. New York: Klewer Academic/ Plenum Publishers.

Harney, J. N., E. E. Grossman, B. M. Richmond and C. H. Fletcher III. 2000. Age and Composition of Carbonate Shoreface Sediments, Kailua Bay, Oahu, Hawaii. Coral Reefs, 19:141-154.

Hoegh-Guldberg, O., P. J. Mumby, A. J. Hooten, R. S. Steneck, P. Greenfield, E. Gomez, C. D. Harvell, P. F. Sale, A. J. Edwards and K. Caldeira. 2007. Coral Reefs under Rapid Climate Change and Ocean Acidification. Science, 318:1737-1742.

Kayenne, H., H. Yamano, and R. H. Randall. 2002. Holocene sea-level changes and barrier reef formation on an oceanic island, Palau Islands, western Pacific. Sedimentary Geology, 150:47-60.

Kench, P. S., J. Chan, S. D. Owen, and R. F. McLean. 2014. The Geomorphology, Development and Temporal Dynamics of Tepuka Island, Funafuti atoll, Tuvalu. Geomorphology, 222:46-58.

Kench, P. S., Ford, M. R. and S. D. Owen. 2018. Patterns of Island Change and Persistence Offer Alternate Adaptation Pathways for Atoll Nations. Nature Communications, 9:605.

Lelaurin, J. 2000. Hydrodynamic Simulation with Mike 21 of Abaiang Atoll, Kiribati. Suva: SOPAC Secretariat.

Lovell, E. R. 2000. Coral Reef Benthic Surveys of Tarawa and Abaiang Atolls, Republic of Kiribati. Suva: SOPAC Secretariat.

McKoy, H., D. M. Kennedy, and P. S. Kench, 2010. Sand Cay Evolution on Reef Platforms, Mamanuca Islands, Fiji. Marine Geology, 269:61-73.

McLean, R., and P. Kench. 2015. Destruction or Persistence of Coral Atoll Islands in the Face of 20th and 21st century Sea-Level Rise? Wiley Interdisciplinary Reviews: Climate Change, 6:445-463.

McManus, J. 1988. "Grain Size Determination and Interpretation”. In Techniques in Sedimentology, ed. M. Tucker, pp 63-85. Oxford, Blackwell Scientific Publications.

Milliman, J. D. 1967. Carbonate Sedimentation on Hogsty Reef, a Bahamian Atoll. Journal of Sedimentary Research, 37:658-676.

Milliman, J. D. 1974. Recent Sedimentary Carbonates Part I: Marine Carbonates. New York, SpringerVerlag.

Mimura, N. and P. D. Nunn. 1998 Trends of Beach Erosion and Shoreline Protection in Rural Fiji. Journal of Coastal Research, 14:37-46.

[MISA] Ministry of Internal and Social Affairs. 2008. Abaiang Island Socio-Economic Profile. Bairiki, Tarawa: Ministry of Internal and Social Affairs.

Morris, M. J., J. D. Collen, R. Smith, and J. E. Patterson, 2003. Sedimentology and Geochemistry of Reef Flat Sediments, Suva, Fiji: Implications for Cement Manufacture. Environmental \& Engineering Geoscience, 9:295-304. 
Munsell. 2000. Munsell Soil Color Charts. Michigan, Grand Rapids.

Nagamoto, C., F. Parungo, B. Kopcewicz and M. Y. Zhou. 1990. Chemical Analysis of Rain Samples Collected over the Pacific Ocean. Journal of Geophysical Research: Atmosphere, 95:22343-22354.

Nel, R., E. E. Campbell, L. Harris, L. Hauser, D. S. Schoeman, A. McLachlan. D. R. du Preez, K. Bezuidenhout and T. A. Schlacher. 2014. The Status of Sandy Beach Science: Past Trends, Progress, and Possible Futures. Estuarine Coastal and Shelf Science, 150:1-10.

Nurse, L. A., R. F. McLean, J. Agard, L. P. Briguglio, V. Duvat-Magnan, N. Pelesikoti, E. Tompkins, and A. Webb, 2014. "Small islands". In Climate Change 2014: Impacts, Adaptation, and Vulnerability. Part B: Regional Aspects. Contribution of Working Group II to the Fifth Assessment Report of the Intergovernmental Panel on Climate Change, eds. V. R. Barros, C. B. Field, D. J. Dokken, M. D. Mastrandrea, K. J. Mach, T. E. Bilir, M. Chatterjee, K. L. Ebi, Y. O. Estrada, R. C. Genova, B. Girma, E. S. Kissel, A. N. Levy, S. MacCracken, P. R. Mastrandrea, and L. L. White, pp. 1613-1654. Cambridge, United Kingdom and New York, USA: Cambridge University Press.

Office of Teberetitenti. 2012. 4. Abaiang. Republic of Kiribati Island Reports Series. Tarawa: Office of Teberetitenti and T'Makei Services.

Paulay. G. 2000. Benthic Ecology and Biota of Tarawa Atoll Lagoon: Influence of Equatorial Upwelling, Circulation, and Human Harvest. Washington DC: Smithsonian Institution, National Museum of Natural History.

Paulay, G., and A. Kerr. 2001. Patterns of Coral Reef Development on Tarawa Atoll (Kiribati). Bulletin of Marine Science, 69:1191-1207.

Perry, C. T. and A. R. Harborne. 2016. "Bioerosion on Modern Reefs: Impacts and Responses under Changing Ecological and Environmental Conditions". In Coral Reefs at the Crossroads, eds. D. K. Hubbard, C. S. Rogers, J. H. Lipps, and G. D. Stanley Jr., pp. 69-101. Dordrecht: Springer.

Perry, C. T., P. S. Kench, S. G. Smithers, B. Riegl, H. Yamano and M. J. O'Leary. 2011. Implications of Reef Ecosystem Change for the Stability and Maintenance of Coral Reef Islands. Global Change Biology, 17:3679-96.

Pilkey, O. H., R. W. Morton and J. Luternauer. 1967. The Carbonate Fraction of Beach and Dune Sands. Sedimentology, 8:311-327.

Ponder, R., and I. Glendinning. 1974. The Magnesium Content of Some Miliolacean Foraminifera in Relation to their Ecology and Classification. Palaeogeography, Palaeoclimatology and Palaeoecology, 15:29-32.

Powers, M. C. 1953. A New Roundness Scale for Sedimentary Particles. Journal of Sedimentary Research, 23:117-119.

Richmond, B. 1990. Nearshore Sediment Distribution, South Tarawa, Kiribati. CCOP/ SOPAC Technical Report 91. Suva: South Pacific Applied Geoscience Commission.

Richmond, B. M. 2000. "Overview of Pacific Island Carbonate Beach Systems". In Carbonate Beaches 2000, eds. O. T. Magoon, L. L. Robbins, and L. Ewing, pp 218-228. Reston VA, American Society of Civil Engineers.

Salmimies, R., M. Mannila, J. Juha and A. Häkkinen. 2011. Acidic Dissolution of Magnetite: Experimental Study on the Effects of Acid Concentration and Temperature. Clays and Clay Minerals, 59:136-146.

Scoffin, T. P. 1992. Taphonomy of Coral Reefs: A Review. Coral Reefs 11(2):57-77.

Shepard, F. P., and R. Young. 1961. Distinguishing between Beach and Dune Sands. Journal of Sedimentary Research, 31(2):196-214.

Short, A. D. 1999. "Global Variation in Beach Systems". In Handbook of Beach and Shoreface Morphodynamics, ed. A. D. Short, pp. 21-35. Chichester: John Wiley and Sons.

Smith, R., and N. Biribo. 1995. Marine Aggregate Resources Tarawa Lagoon, Kiribati- Including Current Meter Studies at Three Localities. SOPAC Technical Report 217, Suva: South Pacific Applied Geoscience Commission.

Smith R., and J. Collen. 2004. Sand and Gravel Resources of Majuro Atoll, Marshall Islands. SOPAC Technical Report 360, Suva, South Pacific Applied Geoscience Commission. 
Solomon, S. M., and D. L. Forbes. 1999. Coastal Hazards and Associated Management Issues on South Pacific Islands. Ocean and Coastal Management, 42:523-554.

Stewart Jr., H. B. 1958. Sedimentary Reflections of Depositional Environment in San Miguel Lagoon, Baja California, Mexico. American Association of Petroleum Geologists Bulletin, 42(11):2567-2618.

Stoddart, D. R. 1965. The Shape of Atolls. Marine Geology, 3(5):369-383.

Stoddart, D. R. 1978. "Mechanical Analysis of Reef Sediments". In Coral Reefs: Research Methods, ed. D. R. Stoddart, pp. 53-66. Paris, UNESCO.

Stoddart, D., and J. Steers. 1977. The Nature and Origin of Coral Reef Islands. Biology and Geology of Coral Reefs, 4:59-105.

Tewfik, A., and H. M. Guzman. 2003. Shallow-Water Distribution and Population Characteristics of Strombus gigas and S. costatus (Gastropoda: Strombidae) in Bocas del Toro, Panama. Journal of Shellfish Research, 22:789-794.

Thaman, R., U. Neemia and N. Teuatabo. 1992. Country Report for UNCED-Kiribati. Rio de Janeiro, Brazil: Report Prepared for the United Nations Conference on Environment and Development.

Thaman, R. R., and A. Tye. 2015. Flora of Kiritimati (Christmas) Atoll, Northern Line Islands, Republic of Kiribati. Atoll Research Bulletin, 608:1-73.

Thomas, F. R. 2001. Mollusk Habitats and Fisheries in Kiribati: An Assessment from the Gilbert Islands. Pacific Science, 55:77-97.

Webb, A. 2006. Analysis of Coastal Change and Erosion- Tebunginako Village, Abaiang, Kiribati. EU EDF 8/9- SOPAC Project Report 53. Suva: SOPAC Secretariat.

Weber, J. N., and P. M. Woodhead. 1972. Carbonate Lagoon and Beach Sediments of Tarawa Atoll, Gilbert Islands. Atoll Research Bulletin, 157:1-28.

Wentworth, C. K. 1922. A Scale of Grade and Class Terms for Clastic Sediments. Journal of Geology, 30:377-392.

Wilson, B. 2013. A Guide to 1,000 Foraminifera from Southwestern Pacific, New Caledonia. Journal of Foraminiferal Research, 43:314-315.

Yamano, H., H. Kayanne and M. Chikamori. 2005. An Overview of the Nature and Dynamics of Reef Islands. Global Environmental Research, 9:9-20.

Yamano, H., H. Kayanne, F. Matsuda, and Y. Tsuji, 2002. Lagoonal Facies, Ages, and Sedimentation in Three Atolls in the Pacific. Marine Geology, 185:233-247.

Yashukochi, T., H. Kayanne, T. Yamaguchi, and H. Yamano, 2014. Sedimentary Facies and Holocene Depositional Processes of Laura Island, Majuro Atoll. Geomorphology, 222:59-67. 